\title{
Potential Military Effects on Selected Plant Communities in the Southeastern United States
}

by

Ann-Marie Trame and Mary Harper

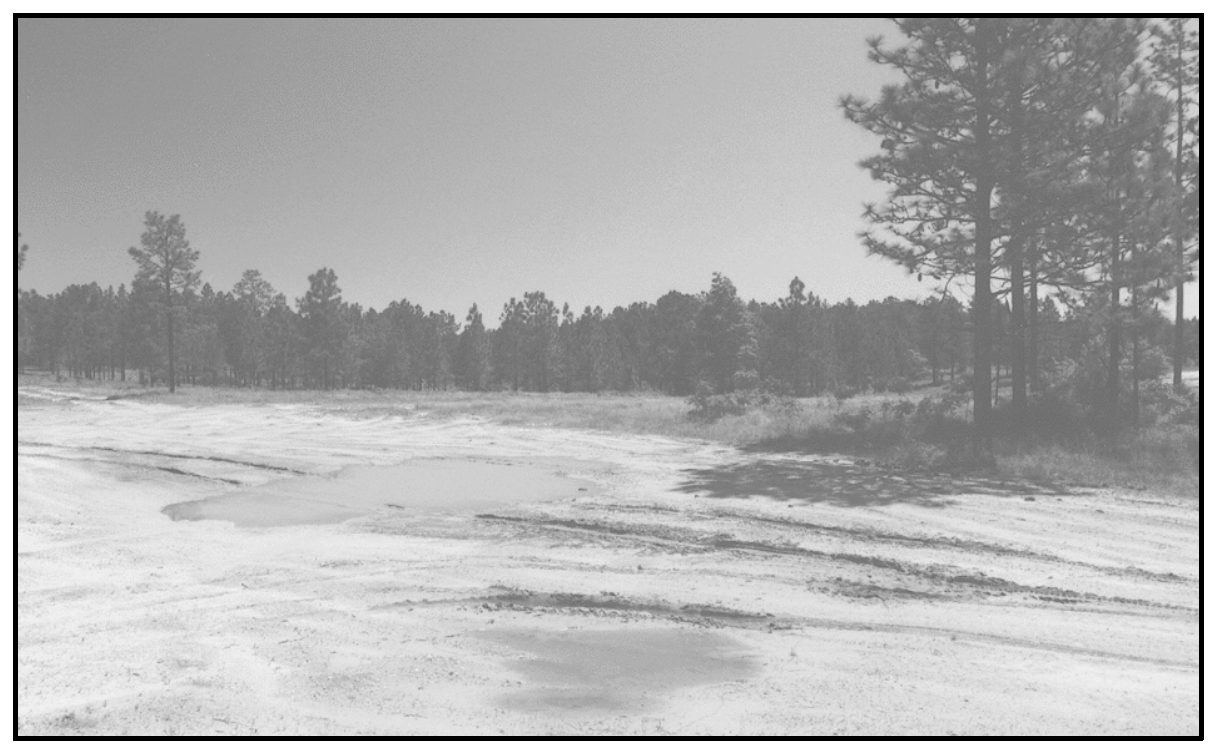

Military training and testing mission requirements make up the highest priority land uses on Department of Defense (DoD) lands. The U.S. Armed Forces require realistic, relatively natural, and expansive areas for adequate training. Training activities can lead to degradation of sensitive natural resources, but they also produce benefits. An ecosystem-based approach to managing threatened, endangered, and sensitive species (TES) and other natural resources provides DoD with an efficient, effective, and flexible framework for evaluating impacts, assessing natural resources, and generating management solutions to potential conflicts between training and TES conservation. Any increase in understanding about the habitat requirements of listed TES species will assist training and natural resource personnel in complying with the
Endangered Species Act while avoiding restrictions on the military mission.

This report is to be used by DoD natural resource policymakers, installation land managers, and the natural resource research community, in conjunction with associated documents produced by this SERDP work unit to (1) develop ecosystem-based approaches to describe natural communities and TES habitat in relation to military activities, (2) evaluate military-related effects on those communities, (3) develop community-based strategies for supporting both military land use and TES habitat management, and (4) develop management solutions for military impacts to natural communities when management for TES habitat is a priority for a particular location.

Approved for public release; distribution is unlimited. 


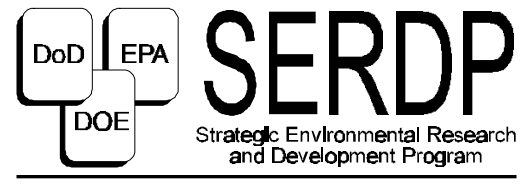

Improving Mission Readiness through Environmental Research 
SF 298 


\section{Executive Summary}

TheU.S. Armed Forces require realistic, relatively natural, and expansive areas for adequate training. Training activities can lead to degradation of sensitive natural resources, but they also produce benefits. An ecosystem-based approach to managing threatened, endangered, and sensitive species (TES) and other natural resources provides the Department of Defense(DoD) with an efficient, effective, and flexible framework for evaluating impacts, assessing natural resources, and generating management solutions to potential conflicts between training and TES conservation (Trameand Tazik 1995, Threatened and Endangered Species Working Group 1995).

This research effort focuses on the potential of military activities to alter high quality plant communities. By managing for plant communities, the DoD has the opportunity to conserve multipleTES simultaneously. Plant communities are less ambiguous entities than ecosystems, and have been described and cataloged for many decades by ecologists and biogeographers. They provide a useful basis on which to understand and manage the natural systems that support both military training and TES. Exactly how and to what extent military impacts may occur to natural plant communities in the Southeast have not been documented.

This report recommends management that promotes the conservation of TES habitat sites and does not intend for application to be made across entire DoD installations. In some cases, these recommendations may appear to conflict with thetop priority of the military training mission. However, themilitary mission and TES habitat are not mutually exclusive. By managing for robust TES populations, installations may benefit from fewer restrictions on land use as a result of the Endangered Species Act (ESA). Installation training and natural resources personnel are constantly challenged to reconcile the needs of TES with the requirements of the military mission. The following recommendations are given to assist in this regard, by providing current information about TES habitat needs.

Recent focus on red-cockaded woodpecker (RCW) management has led to an increase in land area burned by prescribed and mission-related fires, and has increased the quality of plant communities all across DoD lands in the Southeast. This application has benefited numerous plant and animal TES and other taxa that 
depend on RCW and adjacent habitats. An increased focus on hydrologic impacts would move DoD towards moreintegrated TES and natural resources management and would assist decisionmakers in reducing the impacts of intensive training.

Limited areas, such as inclusional wetlands and high quality sites that harbor TES, should be protected from the effects of mechanized activities, such as erosion, sedimentation, compaction, fire suppression, and intensive trampling or ground disturbance. A buffer zone of protection should extend well across ecotones to prevent sedimentation into wetlands, fire suppression due to loss of fuels, or changes to hydrol ogy of wetlands and uplands. However, fire-adapted, high quality, and wetland communities can sustain reasonable levels of nonmechanized military use, as long as digging is not involved.

Longleaf pine woodlands on moist or dry sites can sustain intensive military activities if managed properly. Military training activities should be planned for fewer sites that are permanently altered and used, rather than many sites that are used in rest-recovery rotation. Therecovery phase probably will not be long enough to allow regeneration of the natural community (Cole 1995). When additional occupation or maneuver trainingsites areplanned, fragmentation of thecommunity should be minimized, so that landscape-level hydrologic processes and fire regimes are less disrupted (Hart and Lester 1993). Lower quality communities should be considered for conversion to multipurpose ranges, drop zones, or intensive mechanized maneuver zones. Higher quality sites can be used for less damaging activities such as transient nonmechanized maneuvers.

The dry sandy soils of pine woodlands are susceptible to erosive forces. Although erosion control measures are essential to protect nearby wetlands and streams, the use of invasive exotic species should be avoided when possible. It is important to capture any sediment in runoff from uplands, before it is deposited on lower-lying wetlands or streams (Hart and Lester 1993). This effort is particularly important for small streams that are tightly linked to processes occurring in the surrounding uplands. A buffer zone around small, high quality streams will reduce sedimentation and should conserve hydrologic patterns on which many TES depend. In particular, roadbed stream crossings can bevery damaging, and should be designed to prevent erosion and ponding (LeBlond, Fussell, and Braswell 1994a). Training activity can be funnelled into a single crossing point, using telephone poles along the ground to direct troop movements. These limited crossings can be hardened with concrete or rock. Check dams can also be used on both sides of the streambed to minimize sedimentation from upslope areas (A. Henry, State Biologist, North Carolina NRCS, 15 September 1995). To keep damage local ized, degraded areas 
should be rehabilitated and reused so high quality areas that serve as TES habitat can be avoided altogether (Russo et al. 1993).

Overall, four basictrends are apparent: (1) Because many southeastern ecosystems arefire-adapted, military training is potentially beneficial when it ignites growingseason fires that areallowed to spread across the landscape; (2) Plant communities that are fire-adapted can probably tolerate losses of vegetation due to moderate levels of trampling; (3) Hydrol ogic changes and soil erosion due to military activity, especially tank traffic, have the potential to destroy some plant communities, tothe detriment of TES plant species; and (4) Degradation due to hydrologic and soils impacts has the potential to be less reversible than degradation due to lack of fire or other land use impacts. In fact, these areas may never be restored to the original natural community. Of the communities examined, those that are more firestructured and less sensitive to hydrologic impacts provide the most resilient locations for military use. These areas include drier pine woodlands. Pocosin ecotones, pine savannahs, hillside seeps, and small stream forests are especially sensitive to hydrol ogic changes and can beeasily destroyed by mechanized training. Alluvial forests may be somewhat immune to mechanized training because of very wet soils. However, if mechanized traffic were to occur in alluvial forests, the potential for damage would be great. Such information could be used by military and land management personnel for land use planning. However, current knowledgeis limited, and future research is needed to improve decisionmaking and planning processes. 


\section{Foreword}

This study was conducted for Strategic Environmental Research and Development Program (SERDP), Project 507-94. The technical monitor was Femi Ayorinde.

The work was performed jointly by the Natural Resource Assessment and Managment Division (LL-N) of the Land Management Laboratory (LL), U.S. Army Construction Engineering Research Laboratories (USACERL), and the Natural Resources Division (NRD), Environmental Laboratory (EL), U.S. Army Engineer Waterways Experiment Station (WES). The principal investigator for USACERL was Ann-Marie Trame, and for WES, Chester O. Martin. Mary Harper was a Research Associate under an interagency agreement with the U.S. Forest Service, Rocky Mountain Range and Forest Experiment Station, and Colorado State University. Dr. William D. Severinghaus is Operations Chief, CECER-LL. The USACERL technical editor was Linda L. Wheatley, Technical Information Team.

Appreciation is also due to Steven Parris, Dr. Michael MacRoberts, Barbara MacRoberts, J anet Shipley, Mike Schafale, Rhonda Stewart, Earl Stewart, Phil Pierce, Dr. Marcl mlay, Tom Macia, Dr. Cliff Rice, Kevin Robertson, Dr. Alison Hill, Dr. David Tazik, Dr. David Price, Dr. Richard Fischer, and several personnel at the Army Training Support Center for their assistance in reviewing a draft of this document.

Dr. Michael J . O'Connor is Director of USACERL. 


\section{Contents}

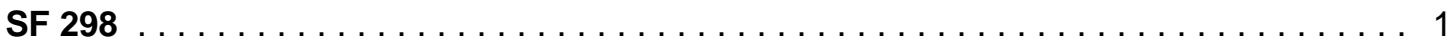

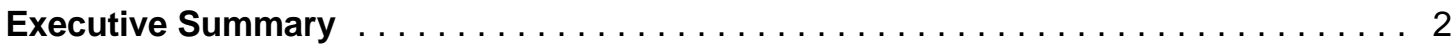

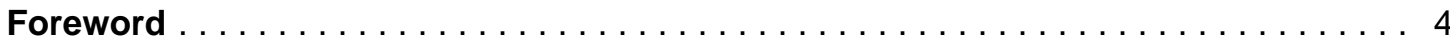

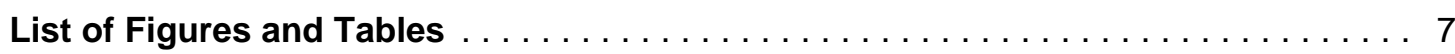

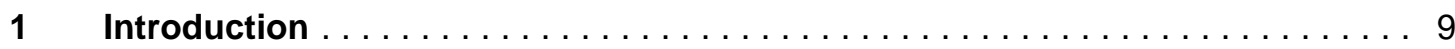

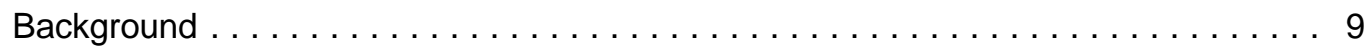

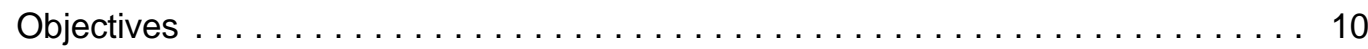

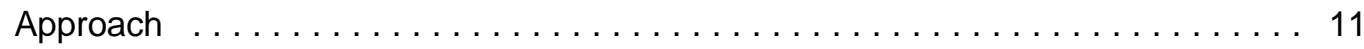

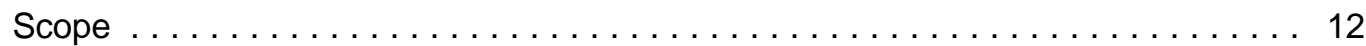

Mode of Technology Transfer . . . . . . . . . . . . . . . . . . . . . 12

2 Natural Plant Communities Known To Support TES in the Southeast . . . . . 13

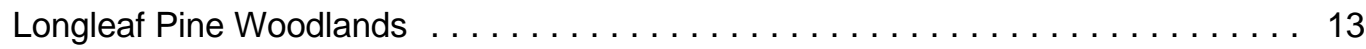

Bottomland Hardwoods and Deepwater Swamps $\ldots \ldots \ldots \ldots \ldots \ldots \ldots . \ldots \ldots$

Inclusional Wetlands . . . . . . . . . . . . . . . . . . . . . . . 15

3 Description of Selected Military Training and Forestry Activities $\ldots \ldots \ldots \ldots$

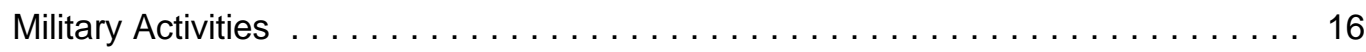

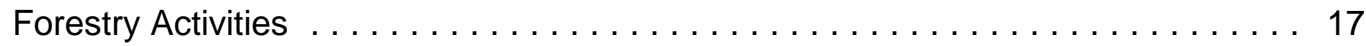

4 General Effects of Military Training on Plant Communities in the Southeast . 19

Direct Impacts to Soils . . . . . . . . . . . . . . . . . . . . . 19

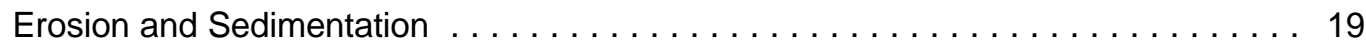

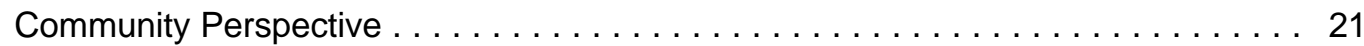

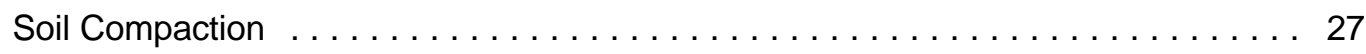

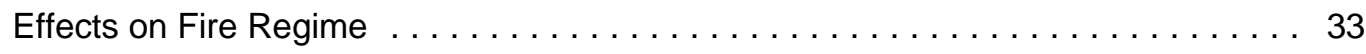

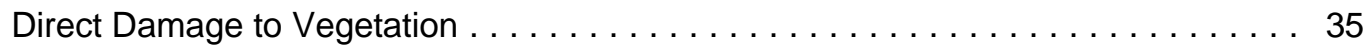

$5 \quad$ Potential for Disturbances in Selected Plant Communities . . . . . . . . . . 37

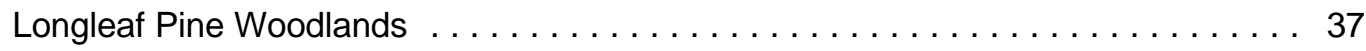

Bottomland Hardwoods and Deepwater Swamps ................ 39

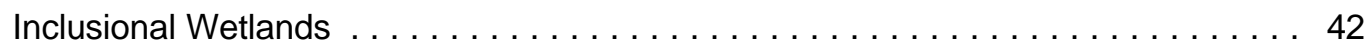


$6 \quad$ Management of Natural Plant Communities for TES Conservation . . . . . . . 46

Management of High Quality, Sensitive, and Rare Communities for TES . . . . . . . 46

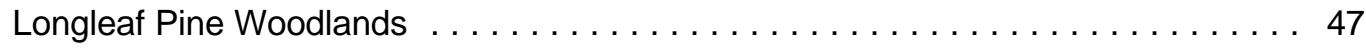

Bottomland Hardwoods and Deepwater Swamps $\ldots \ldots \ldots \ldots \ldots \ldots . \ldots . \ldots 48$

7 Conclusions and Recommendations $\ldots \ldots \ldots \ldots \ldots \ldots \ldots \ldots \ldots \ldots \ldots$

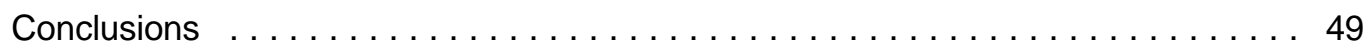

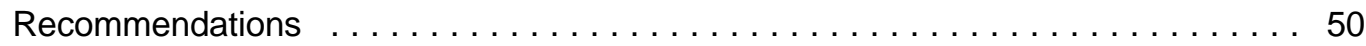

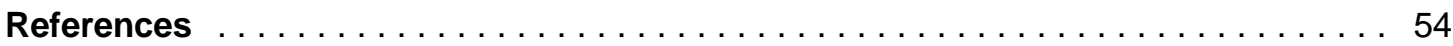

Appendix A: $\quad$ List of Personal Communications Cited $\ldots \ldots \ldots \ldots \ldots \ldots \ldots$

Appendix B: LCTA Data Sources for Assessing Military Impacts to Natural

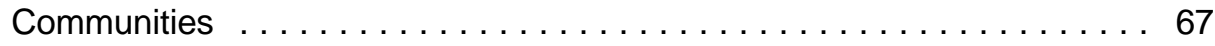

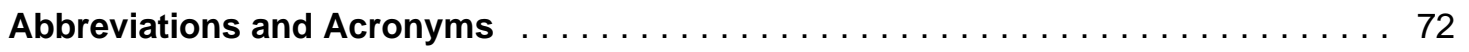

Distribution 


\section{List of Figures and Tables}

\section{Figures}

1 Severe sedimentation in a natural stream caused by intensive tank maneuvers in nearby upland areas . . . . . . . . . . . . . . . 22

2 Damage to soils (compaction), groundcover, and overstory trees typical of areas used for intensive occupation exercises $\ldots \ldots \ldots \ldots \ldots \ldots$

3 Although this occupation site has lost some vegetation, abundant longleaf pine regeneration can be seen in persistent forest islands . . . . . . . . . . . 29

4 Wiregrass is still abundant near the edges of the occupation site . . . . . . . 29

5 Assembly areas and tank maneuver sites become barren, which fragments fuel sources and prevents fire from carrying over large areas . . . . . . . . . . . 34

6 Off-road tank traffic in flatwoods community led to rutting, ponding, fire suppression, and consequential changes in the composition and structure

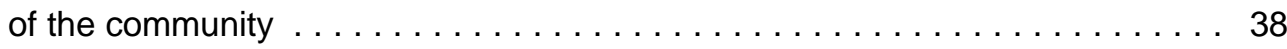

$7 \quad$ Tank traffic through a bog left deep ruts, which fill with water and channel overland water flowC pitcher plants (Sarracenia spp.) no longer grow along the ruts because the soil is too dry . . . . . . . . . . . . . . . . 43

8 A bog drained by tank ruts is now dominated by wax myrtle and St. John's WortC deep ruts remain under the vegetation $\ldots \ldots \ldots \ldots \ldots$. . . . . . . 44

9 A bog that recently became an off-road tank maneuver site shows bog species persist near deep ruts that are channeling water and soils

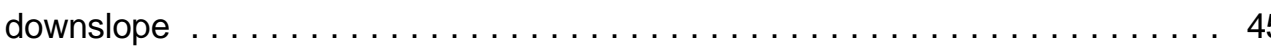

10 This bog area appears to be irrepairably harmed after only a short period

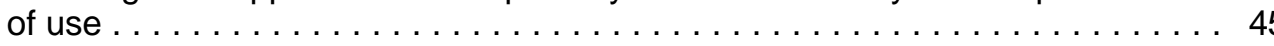

Tables

$1 \quad$ Native plant species that may have potential for erosion control plantings in longleaf pine woodlands . . . . . . . . . . . . . . . . . 26

B1 Panel recommendations that influenced the development of the Army LCTA program .............................. 67 


\section{Introduction}

\section{Background}

Military training and testing mission requirements make up the highest priority land uses on Department of Defense (DoD) lands. It is obvious that the military mission has coexisted with areas of high ecol ogical qual ity for decades, and, in many cases, mission-related activities aredirectly responsi bl efor thesehigh quality areas. The military mission and TES are compatible and should not be thought of as mutually exclusive interests. Any increase in understanding about the habitat requirements of listed TES species will assist training and natural resource personnel in complying with the Endangered Species Act (ESA) while avoiding restrictions on the military mission.

This report is one product of an interlaboratory effort between the U.S. Army Construction Engineering Research Laboratories (USACERL) and U.S. Army Engineer Waterways Experiment Station (WES) to generate habitat-based management strategies for threatened, endangered, and sensitive species (TES) on Department of Defense (DoD) lands in the southeastern United States (Strategic Environmental Research and Devel opment Program [SE RDP] work unit "Regional Guidelines for Managing T\&E Species Habitats"; Martin et al. 1996). This effort is directed at devel oping strategies to assess and manage TES and their habitats, and to emphasize plant community-based strategies, methods that apply to multiple species, and methods that apply across the southeastern region.

Management approaches to protecting TES, other natural resources, and natural plant communities are often designed to address immediate and local problems ( $M$. Imlay, Natural Resource Specialist, Army National Guard Bureau, professional discussion, 18 August 1995). Although this can be a rewarding and effective approach for an individual installation, it precludes any organized understanding of military impacts or sharing of lessons learned, and can sometimes lead to repeated, inefficient efforts to solve similar problems throughout a region of the country. Duplication of effort needs to be reduced or eliminated.

While the U.S. Armed Forces require realistic, relatively natural, and expansive areas for adequatetraining, training activities can result in degradation of sensitive 
natural resources. They can also produce benefits. An ecosystem-based approach to managing TES and other natural resources provides the DoD with an efficient, effective, and flexible framework for evaluating impacts, assessing natural resources, and generating management solutions to potential conflicts between training and TES conservation (Trame and Tazik 1995; Threatened and Endangered Species Working Group, in prep).

Consistent with an ecosystem-based approach and the SERDP work unit, this report focuses on plant communities because they provide habitat for multiple species. By managing for plant communities, DoD has the opportunity to conserve multipleTES simultaneously. Plant communities are less ambiguous entities than complete ecosystems, and have been described and cataloged for many decades by ecologists and biogeographers. They provide a useful basis on which to understand and manage the natural systems that support military training. Exactly how and to what extent military impacts occur to natural plant communities has not been documented and has not been systematically researched. However, in some cases, extensive physical alteration of areas is evident, and field observations by professionals indicate that impacts do occur. This analysis of potential military impacts complements more comprehensive treatments of nonmilitary land use impacts and management for individual plant communities from this work unit (e.g., Harper et al. in prep, Fischer et al. in prep).

\section{Objectives}

The objectives of this research were to compile known information, identify gaps in knowledge, and stimulate future research efforts on the potential positive and negative effects of military-specific activities to plant communities that serve as high quality habitat for TES plants in the southeastern United States. This SERDP work unit, in particular, was undertaken to reduce duplication of effort towards conservation of TES within the southeastern region.

This report was funded as a literature-based assessment of the effects of land-based maneuver training on TES habitat in the Southeast. It is hoped that this review of information may be used to improve the ecological and economic effectiveness of TES habitat management. By understanding the ecological requirements of TES and the environmental resilience or sensitivity of TES habitats, installations acquire increased control over TES management and land use decisions.

Despite the primacy of the military training and testing mission, installations are required to maintain robust TES populations into the foreseeable future. This 
requirement can be achieved within the context of the larger DoD mission through the following framework: (1) identify mission requirements, (2) identify TES requirements, (3) identify ideal compromises for meeting both TES and mission requirements, and (4) pursue these compromises and develop realistic, workable compromises. The fourth step should be executed through professional management of TES populations, as much as possible, to reducerestrictions on the military mission.

This document provides information to assist in identifying the needs of TES (step 2), and perhaps it will assist in identifying options for compromise as well (step 3). This is only a partial contribution to the total process. Furthermore, these results suggest that a great deal of additional effort is required before the process will be guided by solid scientific information (as required by the ESA). Due to the scope of this report, specific management recommendations are to be considered for areas that trainers and resource managers recognize and manage as endangered species habitat. Many of the most restrictiveland use recommendations are madefor areas that are also recognized as protected wetlands due to their sensitive hydrology. These recommendations are not intended to be applied across entire DoD installations.

\section{Approach}

To identify potential military impacts, researchers conducted interviews with community ecologists throughout the southeastern U nited States who have been involved in plant TES and plant community survey work on military installations. Through these interviews, it was learned that little experimental or empirical data are available that directly assess military impacts to natural communities. Site visits were made to military installations. Potential impacts were also discussed with military natural resources personnel, botanists, community ecologists, and military contractors, such as The Nature Conservancy (TNC) or state Natural Heritage Program (NHP) staff. Appendix A is a list of experts contacted. Information also was gleaned from installation TES survey reports in which impacts and management were addressed. Land Condition Trend Analysis (LCTA) reports, Land Rehabilitation and Maintenance (LRAM) data, and academic and Federal agency literature on logging and recreational impacts to plant communities were also used. Appendix B is an assessment of LCTA data and reports for the purposes of understanding potential military effects on TES habitat. 


\section{Scope}

Literature searches and interviews reveal ed a lack of solid scientific information on military impacts to plant communities. It is clear that effects do occur, but they have not been examined rigorously. This report is intended to introduce the field observations of trained biologists and the opinions and hypotheses of trained professionals regarding military impacts to some sel ected plant communities in the southeastern U nited States. It is intended to present current thinking on military impacts and to recommend future research questions. The scope is limited to those plant communities on installations that have been visited and discussed with appropriate experts, and to activities that are specific to military training and ammunitions testing. The plant communities discussed cover the majority of installation land used for land-based training in the Southeast.

Discussions about prescribed burning, plow-line management, forestry prescriptions, and other aspects of natural resource management are not included here, because they are available in other products of the SERDP work unit. In some cases, documented forestry and recreational impacts are used to suggest impacts from similar military activities. Limited discussions of erosion control methods are included, when such information has been found that is compatible with a natural community framework.

\section{Mode of Technology Transfer}

This report is to be used by DoD natural resource policymakers, installation land managers, and the natural resource research community, in conjunction with associated documents produced by this SERDP work unit (e.g., Harper et al. in prep; Harper and Trame in prep; and Fischer et al. in prep) and Trame and Tazik (1995), to (1) devel op ecosystem-based approaches to describe natural communities and TES habitat in relation to military activities, (2) evaluate military-related effects on thosecommunities, (3) devel op community-based strategies for supporting both military land use and TES habitat management, and (4) devel op management solutions for military impacts to natural communities when management for TES habitat is a priority for a particular location. 


\section{Natural Plant Communities Known To Support TES in the Southeast}

\section{Longleaf Pine Woodlands}

Longleaf pine (Pinus palustris) dominated uplands, usually sandhills, occur al ong the outer Coastal Plain from eastern Virginia toF lorida and west tothe Mississippi River. Stands also occupy the fall line* of Alabama, Georgia, North Carolina, and South Carolina. This plant community generally occurs in areas with rolling topography that have well-drained, dry to xeric sandy soils (Stout and Marion 1993). Examples occur on more than 20 military installations in the Southeast (Harper et al. in prep).

Sandhill community structure is characterized by an open, sparse canopy of pine, an open understory dominated by scrubby oaks, and a herbaceous ground layer consisting of various grasses and forbs (Myers 1990). Physiognomy (form and threedimensional structure of a plant community) varies with moisture, fire regime, and geographic location. Longleaf pine dominates the canopy, except in southeastern and southcentral Florida stands, which may consist of slash pine (P. el liottii) or both longleaf and slash pine, and in eastern Texas, where shortleaf ( $P$. echinata) and loblolly pine (P. taeda) are common north of the range of longl eaf (Christensen 1988; Stout and M arion 1993). In some cases, the pine canopy has been removed and the understory scrub oaks have become dominant (Myers 1990). Turkey oak dominates the understory in xeric sites east of the Mississippi River, but in the Big Thicket region of eastern Texas, bluejack oak (Q. incana) and post oak (Q. stel lata) replace turkey oak (Christensen 1988, Stout and Marion 1993). In Louisiana, blackjack oak, sandhill oak, and bluejack oak are common components of longleaf pine communities (L. Smith, Community Ecol ogist, Louisiana Natural HeritageProgram professional discussion,J anuary 1997). Wiregrass (Aristida stricta in theCarolinas; and $A$. beytrichiana in southern South Carolina, and Florida west to J ackson County, MS; Peet 1993) dominates the understory in community occurrences east of eastern Mississippi. In less xeric habitats and west of the range of wiregrass (A.

\footnotetext{
* The fall line marks the separation between the Piedmont and Coastal Plain physiographic regions in the southeastern United States.
} 
stricta and A. beytrichiana), bluestems (Schizachyrium spp.), and broomsedges (Andropogon spp.) increase in importance (Harcombe et al. 1993; Peet and Allard 1993).

Pine flatwoods occur on the Coastal Plain from southeastern Virginia south to Florida and west to Texas, and have been documented on over 20 military installations (Harper et al. in prep). This community occurs on extensive flats or terraces, and has low, usually flat topography (Stout and Marion 1993). The soils are generally poorly drained sands with varying amounts of clay (Abrahamson and Hartnett 1990). Pine flatwoods typically have an emergent treelayer of pines with limbless lower trunks and a ground layer of low vegetation, but physiognomy varies markedly with fire regime and moisture (Stout and Marion 1993). Longleaf pine, slash pine, and pond pine (P. serotina) usually dominate the canopy in pure stands or various combinations. This plant community supports a variety of understory species. The dominant grass is wiregrass east of eastern Mississippi (Stout and Marion 1993). Other important grasses (and dominant grasses outside the range of wiregrass) are bluestems, broomsedges, muhlys (Muhlenbergia spp.), dropseeds (Sporobolus spp.), and toothache grass (Ctenium aromaticum) (Harcombe et al. 1993; Peet and Allard 1993).

\section{Bottomland Hardwoods and Deepwater Swamps}

Bottomland hardwood forests and deepwater alluvial swamps are forested wetlands* that include stream and river floodplain forests and basin mixed hardwood forests of the southeastern United States. These floodplain forests are characterized by high biomass, relatively high stem density of adult trees, and large individual trees forming a high canopy (Brinson 1990). Trees may have low stem density, however, in areas with persistent inundation (Sharitz and Mitsch 1993). Bottomland hardwoods were classified as Palustrine Wetlands in the National Wetlands Classification System and Inventory (Cowardin et al. 1979), as Riverine Wetlands by Brinson (1990), and are a type of riparian community (e.g., Turner, Forsythe, and Craig 1981; Taylor, Cardamone, and Mitsch 1990; Sharitz and Mitsch 1993). Bottomland hardwoods occupy themajority of natural riparian areas in the United States (Huffman and Forsythe 1981, Mitsch and Gosselink 1986); they are dominated by a variety of woody plant species adapted to survival in an

\footnotetext{
Wetlands are transitional habitats between terrestrial and aquatic systems. They are defined as those areas that are inundated or saturated by surface or ground water at a frequency and duration sufficient to support, and that under normal circumstances do support, a prevalence of vegetation typically adopted for life in saturated soil conditions (wetlands generally include swamps, marshes, bogs, and similar areas) (33 CFR328.3(b) 1984).
} 
environment where soils within the root zone may beeither inundated or saturated during various times of the growing season (Sharitz and Mitsch 1993). Deepwater alluvial swamps typically are dominated by cypress (Taxodium spp.), and occur throughout much of the range of southern bottomland hardwoods in depressions (e.g., abandoned river channels, elongated sloughs) that are inundated during most or all of the growing season (Penfound 1952; Sharitz and Mitsch 1993).

\section{Inclusional Wetlands}

Herbaceous wetlands are dominated by grasses, sedges, and composites with an absence of a shrub layer or a tree canopy (although scattered trees or shrubs may occur). They are characterized by frequent fire, acidic soils, seasonal flooding or frequent saturation, and the occurrence of canivorous plants (F rost, Walker, and Peet 1986; Penfound 1952).

Also included in this category are Coastal Plain depression pond complexes, which are complexes of small, isolated, either seasonally or permanently flooded depressions in pinelands (Bridges and Orzell 1989; Florida Natural Areas I nventory (FNAI) and Florida Department of Natural Resources (FDNR) 1990; Schafale and Weakley 1990; Wharton 1978). These communities are included because they have similar hydrologic properties to seep and bog communities, and they provide important breeding sites for amphibians.

All of these communities occur as small inclusions in larger, surrounding pineland communities and usually are not treated separately in literature syntheses regarding southeastern plant community classifications (e.g., Christensen 1988; Stout and Marion 1993; Myers and Ewel 1990). They are treated as a unit here becausethey support high species diversity, including several rarespecies, and they generally have unique soil and hydrologic characteristics, which make them more sensitivetohuman-related disturbancethan their surrounding communities. Thus, they require management and protection in addition to that prescribed for the surrounding landscape. 


\section{Description of Selected Military Training and Forestry Activities}

Thefollowing basic descriptions of military and forestry activities, as defined in this report, are provided to enhance the reader's general understanding of how these activities may affect soils, hydrology, and vegetation. A technical understanding of military doctrine is not needed here, because specific military exercises are not related to effects on vegetation in the available literature or in this document. The effects of mechanized vehides used in forestry are discussed, becausethese impacts have been described in the literature, and may be comparable to mechanized military training impacts. However, caution should be used when applying information from forestry literature to the primary question of military impacts.

\section{Military Activities}

Dismounted training occurs during portions of training exercises when soldiers are on foot. Troops conduct activities that involve either movement or the occupation of areas. Movement impacts on natural resources can be similar to thosegenerated along hiking trails. Platoons and companies must master the skills of tactical movement in units of 33 to 120 soldiers, and they are expected to operate in any terrain and under any weather conditions (DMA 1994). Infantry units are dispersed throughout a large area with missions that require synchronized but decentralized operations (Army Field Manual [FM] 71-100).

Impacts associated with the occupation of area may be similiar to those seen in civilian campgrounds. Additional, more disruptive impacts can occur in military operations such as the preparation of defensive positions, which requires digging in doctrinally determined patterns. Activities associated with the occupation of area occur any time a unit stops to set up security, rest soldiers or equipment, construct fighting positions, camouflage vehicles and equipment, or stay in one place for any length of time (DA 1993). Firing points and any other areas where troops gather can experience the same damage. Occupation impacts involve less area than movement impacts but aremoresevere. Occupation is often accompanied by various levels of mechanized vehicle operations. 
Mechanized and armored units are equipped with heavy tracked vehides (e.g., main battle tanks, Infantry Fighting Vehicles, and Cavalry Fighting Vehicles). They provide mobile, well-protected firepower. They are deployed over large open areas where long-range weapons can be fired with flat trajectories. Movement can occur almost anywhere on the terrain-up and down hills, through streams, and near water. Becausethe terrain is used for protection, maneuvers such as avoiding open space, avoiding open or high ground, or using depressions for concealment must be practiced (FM 7-7). During offensive operations, missions include rapid concentrations of power, so mobility is extremely important, and this requires large expanses of open training terrain (FM 71-100). Mechanized and armored training cause impacts resulting from (1) "violently executed vehicle movement" and (2) sustained weapons fire (DMA 1994).

The modern soldier relies on terrain to provide concealment and protection. The terrain is used and modified by both infantry, armor, and combat engineers. For example, soldiers dig foxholes and tank positions. Engineers must know how to reduce enemy obstacles, create friendly obstacles, and protect sol diers from enemy fire by altering the terrain (FM 5-100). Engineer units use modified tanks, road graders, bulldozers, backhoes, High Mobility Multi-Purpose Wheeled Vehicles (HMMWVs), and front-end loaders. Their activities require movement of massive amounts of many layers of soil. Even the deepest root systems of plants can be destroyed (Trame 1997).

An Army division includes hundreds of support and service units. Signal units must plan, provide, and maintain communication systems between command posts and fighting units. They use light to medium-sized trucks. Combat service support units provide various types of logistics support, using trucks and HMMWVs. The potential for their impacting natural resources is localized and generally less than for combat units.

\section{Forestry Activities}

As described in Harper et al. (in prep):

... forestry practices in [southeastern] pine[woodlands] includesitepreparation activities such as disking and chopping, ditching and draining, bedding, and fertilization. Disking is used to ameliorate soil compaction and improve drainage. Steel blades that penetrate deep in the soil are utilized to cut and break small stems and roots. Disks are most frequently pulled by crawler tractors, but rubber-tired skidding tractors may be used. Chopping is used to sever standing vegetation. Chopping involves rolling a heavy steel drum 
studded with radially oriented cutting blades across a site. Drums can be pulled by an articulated rubber-tired skidder or crawler tractor. Ditches and drains are developed to improve drainage and soil aeration for tree growth. Another practice to improve drainage is bedding, the formation of mounds of soil using bedding plows pulled by crawler tractors or rubber-tired skidders (Lowery and Gjerstad 1991).

...Pinestraw raking is the harvest of fallen pine needles in natural pine communities and plantations. Pinestraw can be raked by hand, or by using tractor-drawn hay rakes and balers to harvest the pinestraw. Logging in [pine woodlands] occurs on ground (vs. skyline cable logging) and includes the use of heavy machinery (wheel or crawler tractors), the creation of haul roads, and use of log decks and skid trails (Hatchell, Ralston, and F oil 1970). 


\section{General Effects of Military Training on Plant Communities in the Southeast}

\section{Direct Impacts to Soils}

Mechanized military training can alter natural plant communities through impacts to soils. The U.S. Geologic Survey (USGS) determined that all soil types examined are vulnerable to off-road vehicle (ORV) damage except for a few clay-rich soils on slopes of less than 10 percent. Sandy and gravelly soils tend to become stripped of vegetation and subsequently suffer gully erosion. ORV use compacts most clay soils until the surface is sealed from water penetration, which can result in increased runoff and gully erosion. Soil structure can also be damaged-top layers can be pulverized, whilelower layers becomeso compacted they cannot support vegetation (Sheridan 1979).

\section{Erosion and Sedimentation}

\section{Impacts}

Human activities that compress or expose soil, alter its porosity and hydraulic conductivity, or reduce plant cover can accelerate erosion. For example, soil compaction, which can result from forestry practices or military activities conducted with heavy machinery, leads to decreased water infiltration and increases in water yield, streamflow rates, and storm flow* volume. This increase in water flow (both over land and through stream beds) has higher erosive force than normal (Vachta and Riggins 1990). Natural factors such as slope, precipitation, and soil texture influence erosion rates as well.

Mechanized training has the greatest potential for erosion impacts on military installations. Although DoD land managers monitor and manage erosion, no studies have been conducted in the Southeast to quantify erosion damage from military activities. Potentially, information about southeastern forestry research

\footnotetext{
* Stream flow attributable to a storm.
} 
may be extrapolated to military impacts. However, it is not clear how well this information reflects actual military impacts. Land use patterns differ between forestry activities and military training. When skidding trees, forestry equipment operators create roads on areas that appear able to sustain vehicle traffic (Aust et al. 1993), and they traverse roads more or less consistently during a relatively brief harvesting timeframe. In addition, theforest products industry has madeimprovements in machinery design in order to minimize soil damage (Greene and Stuart 1985). Although these factors differ in quality among forestry operations, military training strategies are much different, and military maneuvers are more likely to affect larger areas of land over long periods of time. Nonethel ess, some documented impacts of mechanized forestry operations are discussed below.

In east Texas uplands, forestry practices can lead to significant increases in surface water runoff (storm flows). Small watersheds (up to 25 percent gradient) that were clearcut, sheared, windrowed, and burned had higher storm flow volumes than thosethat wereclearcut, roller chopped, and burned, while undisturbed watersheds had the lowest storm flow volumes. These differences declined through time but were still present after 4 years (Blackburn et al. 1987). Clearcut harvesting al one leads tohigher storm flow, probably duetoreduced evapotranspiration and reduced soil infiltration rates (Blackburn et al. 1987). Significant effects from site preparation (shearing plus windrowing or roller chopping) were documented as well. Since shearing and windrowing create more soil disturbances, they lead to larger storm flow increases than does roller chopping (Blackburn et al. 1987).

Clearcutting and site preparation can result in significant increases in erosion as well (Blackburn et al. 1987). In a Louisiana study, the combination of a seedtree cut, chopping or harrowing, and then burning resulted in more erosion than did thinning plus subsequent prescribed burns on a 3-yr. rotation (Wood et al. 1987). However, losses from all experiments were well within the range of natural sediment loss measured from undisturbed watersheds in the Southeast (trace amounts to $648 \mathrm{~kg} / \mathrm{ha}$; Yoho 1980). As vegetation cover increases through time after site preparation, smaller levels of sediment are lost through storm flow or runoff (Blackburn et al. 1987).

The importance of vegetative cover was also demonstrated after fire in sandy loam sites in Louisiana. For a brief period in which bare soil was exposed, burning increased sedimentation rates. Sedimentation rates were also influenced by grass cover, bulk density at 2-in.* depth, and surface silt. In contrast, sedimentation did 
not increase at all after burning on silt-loam soils in the same study. Although the potential for soil loss exists after burning an erosive silt-loam site, the rapid recovery of plants on these soils and flat terrain prevent perpetual losses (Dobrowolski, Blackburn, and Grelen 1987). Thus, the interactive effect of vegetation loss and soil disturbance is critical.

Most erosion from forestry results from poorly constructed and maintained roads, especially if traffic moves perpendicular to drainage ditches or natural contours of the land (Yoho 1980; Askew and Williams 1984). It is possible that similar effects occur as a result of military vehicle movement, since careful road placement and maintenance are not the highest prioirities in battlefield simulation exercises. Sandy upland soils generally suffer as well from gully erosion, which channels water movement and carries the sandy soils into lower-lying areas, thus producing significant impacts on both upland and lowland communities. On some military installations, erosion and siltation from mechanized training activities present the greatest impacts to natural communities and rare species (A. Trame, pers. obs., J . Proffitt).

Knowledge about recreational ORV use may also provide insight into potential military impacts. (Unfortunately, available data come from outside the southeast region, and it is unknown how such data apply to the primary question of military impacts in the Southeast). At Land-Between-the-Lakes, KY, a hardwood forest recreational area, ORVs increased the erosion depth along trails 26 percent in 1 year. Bel ow steep, heavily used slopes, sedimentation and siltation werenoticeable problems (Sheridan 1979). ORV use in the Mojave Desert completely denuded 220 ha and severely damaged another 388 ha over a 10-year period (Sheridan 1979). This type of damage will increase wind erosion and is a major cause of dust storms in the area. In the foothills of the San Gabriel Mountains, CA, ORV damage to hills has buried productivegrasslands downsl opeand increased er osion rates eight times over the natural condition (Sheridan 1979). This kind of damage is associated with unmitigated, intensive vehicle use on poorly vegetated slopes, and may be more severe than that expected from military operations.

\section{Community Perspective}

Uplands. Erosion and sedimentation do not appear to be a significant problem in pine flatwoods due to their flat topography (Swindel et al. 1983; A. Weakly, Southeast Regional Office, TNC, professional discussion, 12 May 1995). For example, sediment in streams and forest road ditches does not move appreciable distances and is thought to be from localized erosion. Although timber harvesting results in 
increased water yield and flow rates because of decreased transpiration rates, these increases are short lived compared to the changes seen in other ecosystems (Swindel et al. 1983). Longleaf-pine sandhills are highly susceptibleto gully erosion if training activities are sustained, intensive, or occur on sloped terrain. Long-term losses of water and nutrients through this process may threaten the integrity of some upland areas (Russo et al. 1993). Some uplands have been degraded by ongoing, large-scale siltation as well, although this is less common (Russo et al. 1993).

Lowlands. E rosion impacts are most damaging when sediment is deposited in wetland basins, streams, or lakes (Russo et al. 1993). Streamhead pocosins (swamps) and other wetlands that areassociated with sandhills are probably most at risk, but a comprehensiveassessment is needed to verify this hypothesis. Sedimentation can also affect alluvial forests (Figure 1) and deepwater swamps. Small, narrow, bottomland forest systems are more affected by upland influences such as runoff and sedimentation compared with large bottomland forest systems along major rivers (Patrick 1981). Sedimentation can alter natural aeration, and nutrient and water conditions (Russo et al. 1993). Deep deposits of sand can smother understory plants and eventually kill overstory trees. Species that normally do not occur in alluvial forests may have a competitive advantage in the new sandy substrate. Sedimentation also creates drastic changes in the aquatic system (Russo et al. 1993). The actual impacts of military activities on sedimentation in wetland basin

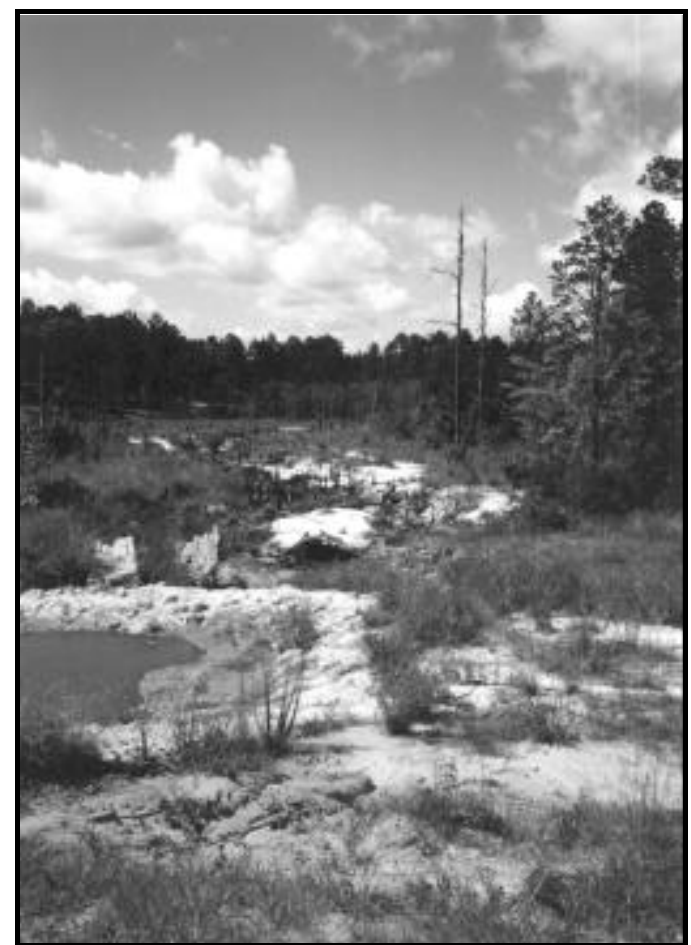

Figure 1. Severe sedimentation in a natural stream caused by intensive tank maneuvers in nearby upland areas. and bottomland communities in the Southeast are unknown. However, sedimentation is a potentially serious threat and should be frequently monitored in any wetland community that harbors TES.

Fertilizer used to enhance plant establishment and growth in erosion control projects may significantly impact wetlands. The additional nutrients may move with the groundwater through sandy soils and enter wetlands. Because many wetland species are adapted to nutrient-poor conditions, the addition of fertilizer may alter nutrient regimes and lead to invasion of the wetland communities with species that are inappropriate (reviewed in Harper and Trame in prep). The significance of this potential impact deserves investigation, because 
erosion control measures are an essential management activity on southeastern DoD lands used for land-based training.

\section{Management}

Erosion control is an essential component of sound land management and TES conservation on DoD lands in the Southeast. Areas used for intensive, repeated vehicle maneuvers or occupation exercises will lose vegetation and contribute to erosion, which can affect entire drainages. If the erosion process can behalted early in development, and erosion can be restricted to the smallest area possible, options for land use will remain more flexible. Although erosion cannot be prevented entirely, it may beharnessed before it severely damages wetlands, lowlands, stream courses, TES habitat, or other sites in which ecological quality is valued.

Prevention. Two management rules may improve planning and implementation of an erosion management strategy: (1) manage for quality wetlands, stream courses, and ponds/lakes, and (2) attack erosion and sedimentation problems quickly. If wetlands and waterways are high quality, the ecological status of uplands and terrestrial systems is probably acceptable as well. This assumption is not to suggest that managers should not monitor terrestrial sites, but that wetlands and streams can serve as critical indicators for overall ecosystem status. Erosion damage should be repaired before it becomes a major obstacle to training or a threat toTES habitat sites, which will be more cost-effective and sustainable in the long term. In the sandy soils of the Southeast, small gullies quickly degrade over short distances into deep gouges that continue to cut back and erode even with aggressive mitigation measures (A. Trame, pers. obs.). Most of the following recommendations to reduce erosion, through improved forestry or training area management, are offered by J ordan, Wheaton, and Weiher (1995) and Department of the Air Force (1993):

1. Avoid construction of plowed fire lines near stream corridors, and stabilize or revegetate emergency lines immediately after fire suppression.

2. Do not construct logging roads and skid trails on slopes with erodible soils or within $30.5 \mathrm{~m}$ of streams. When logging is completed, access roads should be blocked off and revegetated with native species.

3. Evaluate all stream crossings for their contribution to erosion. Close those that are unnecessary or damaging to sensitive species and habitats. A flat concrete pad that does not alter natural water flow and prevents soil disruption (known as an "I rish Bridge") is oneinexpensivealternativeto culverts; this device has proven highly successful at Fort Pickett, VA (J . Proffitt). 
4. In areas used for dismounted infantry training, flag and protect wetland ecotones and ephemeral ponds to prevent unnecessary ORV impacts.

5. Evaluate the necessity of the existing road network and any proposed road construction. All unnecessary secondary roads should bestabilized, closed, and revegetated. New roads should be compatible with the natural contours, hydrologic flows, and erosive potential of the soils, slope, and wetland locations. Road maintenance standards should be raised to reduce erosion from road shoulders.

6. Avoid any nonmission-related activities, such as clay and sand removal, that might increaseerosion and consequent sedimentation intoflatwoods, ecotones, or adjacent wetlands (Russo et al. 1993).

Some erosion is unavoi dable as a result of the nature of the military training mission, especially on Army lands. However, much erosion results from nonmissionrelated off-road driving, especially unplanned "turn-arounds"( $\mathrm{J}$. Proffitt). I mproved communication and environmental awareness activities may reduce the frequency of these maneuvers.

Combat engineer training requires realistic practice in bridge construction and fording of waterways. This practice can be damaging to natural streams and rivers, especially when training schedules are heavy. Fort Pickett VA has devised an alternative strategy for this type of training-an artificial pond was constructed, blocked by large berms, and serviced by hardened parking areas. Military units can access the water from several different angles, and are not constrained by weather or moisture concerns, nor will they cause impact to the natural system. In addition, no off-site impacts are known to be affecting the nearby landscape (J. Proffitt).

Control. DoD land managers are encouraged to work proactively with the Natural Resource Conservation Service (NRCS), state Departments of Transportation, and land management research facilities to receive site-specific erosion management and mitigation assistance ( . Williamson, Range Soil Conservationist, NRCS, professional discussion, 18 December 1995). In areas where intensive maneuver training will continue, traditional intervention using mesh nets, straw, rocks, and fast-growing grasses may be most appropriate because it is critical to stabilize the soil quickly ( . Williamson). However, there is growing awareness that the introduction of non-native species (directly or indirectly through the spreading of straw) for soil stabilization is a serious and fast-growing threat to natural communities in the region. I nvasive erosion control species have repeatedly spread from intended sites to become the dominant vegetation in what had previously been high quality areas capable of supporting TES. The invasion of an exotic plant is usually comprehensive, and it often kills all other vegetation. The problem of 
invasive exotics does not threaten military training directly, although it could reduce training realism. More importantly, invasion of one or more exotic plant species could severely affect an installation's ability to conserve TES in general, which indirectly may lead to restrictions on training if TES populations decline. Cogon grass (Imperata brasiliensis) and Bahai grass (Paspalum notatum) are al ready identified as invasive species that are severely disrupting native plant communities in Florida (FEPPC 1995). J apanese honeysuckle (Lonicera japonica), kudzu (Pueraria montana), and Australian pine (Casuarina cunninghamiana) are other species used for erosion control that haveseriously impacted thesoutheastern region (Gordon and Thomas in prep). Efforts to control erosion near sensitive high quality areas should avoid the introduction of exotics because of the invasion risk. Often, trails and roads provide vectors for movement of exotic plants (Greenberg, Crownover, and Gordon 1997), so monitoring of such areas may detect the early stages of an invasion. Removal of exotics within 5 to $10 \mathrm{ft}$ of trails and roads can be an effective means of slowing invasion into sensitive areas where their presence would threaten TES (M. I mlay, 5 J une 1997).

In the long term, exotics can lead to more ecological damage than the original erosion problem. The possible risks for invasion should be rigorously explored before planting near susceptible communities. The use of love grass (E ragrostis spp.) for erosion control in the longleaf-pine ecosystem is of concern to some biologists (M. Schafale, Community Ecologist, North Carolina Natural Heritage Program, professional discussion, 11 May 1995). In the last year, evidence of love grass expansion has been noted on Fort Bragg (J . Shipley, Endangered Species Biologist, Fort Bragg, NC, professional discussion, 18 March 1996).

Some land managers feel that using exotics is appropriate as a last resort for the control of erosion in sites that will receive continued heavy use (J .Proffitt). It may be acceptable to use annual grasses that do not out-compete native species over the long term (J. Williamson) rather than trying to revegetate with natives that are either slow to establish or do not have large enough seed sources to be practical.

Some military installations have discovered that the use of fertilizer and exotics in the longleaf pine woodlands (e.g., F ort Polk, LA) may not be a problem. Once the use of fertilizer is discontinued, native species often out-compete the exotics and regain their place in the community (S. Parris, Ecologist, Fort Polk, professional discussion, 25 J uly 1995). This approach was supported by D. Lane (Manager, J amie L. Whitten Plant Materials Center, Mississippi NRCS, professional discussion, 12 September 1995) and J. J ohnson (Forester, Alabama NRCS, professional discussion, 27 September 1995). However, others have expressed concern that these practices may lead to invasions by exotic plants, or that applied 
fertilizers will maketheir way into wetlands and streams, altering nutrient regimes and seriously degrading these sensitivecommunities. During revegetation of areas that have been impacted by grazing or timber harvests, planting of exotic species and application of fertilizers have caused more damage than the original soil disturbance and vegetation losses (U.S. Forest Service [USFS] Representative, professional discussion, 1995). Further applied research is required to assess the risks involved for different TES species, plant communities and soil types.

It is hoped that native grasses, such as switchgrass (Pani cum virgatum) and broom sedge (Andropogon virginicus), in conjunction with forbs such as goat's rue (Tephrosia virgi niana) and partridge pea (Chamaecrista fasciculata; seeTable 1 for a complete list of potential erosion control species), can soon be used for erosion control in the longleaf pine woodlands. Additional research is needed to help describe the best methods for using these species (D. Lane). To date, revegetation with native species has been hampered by slow germination and establishment

Table 1. Native plant species that may have potential for erosion control plantings in longleaf pine woodlands.

\begin{tabular}{|c|c|c|}
\hline Common Name & Scientific Name & Reference \\
\hline \multicolumn{3}{|l|}{ Grasses } \\
\hline Bluestem, Chalky & Andropogon capillipes & D. Lane \\
\hline Bluestem, Pinehill & Andropogon divergens & D. Lane \\
\hline Bluestem, Big & Andropogon gerardii & D. Lane \\
\hline Bluestem, Slender & Andropogon tener & D. Lane \\
\hline Broom Sedge & Andropogon virginicus & D. Lane, R. Hansard \\
\hline Grass, Carpet & Axonopus affinis & D. Lane \\
\hline Wild rye, Virginia & Elymus virginicus & D. Lane \\
\hline \multirow[t]{2}{*}{ Panic grass, beaked } & Panicum anceps var. rhizomatum & D. Lane \\
\hline & Dicanthelium spp. & D. Lane \\
\hline Switchgrass & Panicum virgatum & D. Lane, R. Hansard, J. Johnson \\
\hline Grass, Indian & Sorghastrum nutans & D. Lane \\
\hline Purpletop & Tridens flavus & D. Lane \\
\hline Uniola, Long leaf & Uniola sessiliflora & D. Lane \\
\hline Grass, Three-awn & Aristida spp. & R. Hansard \\
\hline \multicolumn{3}{|l|}{ Legumes } \\
\hline Partridge pea & Chamaecrista fasciculata & D. Lane, R. Hansard \\
\hline Rue, Goat's & Tephrosia virginiana & D. Lane \\
\hline Ticks, Beggar's & Desmodium spp. & D. Lane \\
\hline
\end{tabular}


rates (D. Lane; J . J ohnson), limited seed sources (R. Stewart, 24 J uly 1995), and a lack of research on southern ecotypes for this purpose (R. Hansard, Plant Materials Specialist, North Carolina NRCS, professional discussion, 14 September 1995). Research is underway to identify appropriatenative species and propagation/application methods for erosion control on tank maneuver sites at Leesburg Training Site, SC (research proposal, "Development of Vegetative Management Strategy for Disturbed and E roded Areas on Military Training Areas," submitted to the South Carolina Army National Guard, September 1994). On sandy slopes, soil treatments such as disking combined with grass seeding may be less effective than handconstructed flow diversions to reduce the enlargement of gullies (Miller and Sirois 1986).

\section{Soil Compaction}

\section{Impacts}

Adequate data are not available to evaluate the specific impacts of military activities on soil compaction in the Southeast, although a general consensus exists regarding the effects of training on soil compaction. Therisk of compaction depends on the number of passes the vehide makes (intensity), the weight of the vehicle, tire contact pressure, soil type, and moisture conditions. At 80 percent saturation, soils suffer peak compaction (DA 1994). At greater than 80 percent saturation, there is no additional risk of compaction, but the soil structure will be easily damaged and the surface will become "sealed."

Theweight of the vehide determines the degree of subsoil compaction. Deeper compaction caused by heavier machines has longer effects. Different soils havevarying capacities for damage from vehicle training. Soil properties such as bearing capacity (the ability to bear a load without settling or rutting) and traction capacity (ability to provideresistanceagainst a moving vehiclewithout causing slippage) can reduce the depth of impacts (DA 1994).

Researchers have quantified compaction impacts from military training in other regions. In central Texas, increased intensity in tank traffic led to a 2-yr decline in infiltration rates on wet soils. No immediate significant increase in erosion occurred, however. Erosion increased greatly after 2 mo., when the processes of soil shrinkage and swell ling had loosened the soil surface (Thurow, Warren, and Carlson 1993). Evidence suggested that damage may be long term. On a heathland in northern Europe, measurable effects in soil compaction, pH, nutrient content, and 
visible ruts were still present 19 years after tank training occurred in 1963 (Beije 1987).

Military occupation of areas, which involves a combination of vehicle and nonmechanized trampling, can be a serious source of soil compaction and related impacts. Casual inspection of occupation sites in Minnesota, Virginia, and Louisiana revealed a barren understory with few herbs or shrubs, stressed overstory trees, and highly compacted soils (Figure 2; A. Trame, pers. obs.). Trumbull et al. (1994) found a significant increase in bulk densities in a long-term bivouac site in the Missouri Ozarks compared with nearby control sites, but infiltration rates were not different, and the radial growth of overstory trees was comparable. Negative effects from the compacted soils could have been balanced by release of competition, since stem densities were much lower in the occupation areas (Trumbull et al. 1994). The most serious consequence from recreational camping (and probably military occupation as well) is thereduction in reproduction of woody species due to direct destruction and limited germination and survival of seedlings (Kuss and Graefe 1985). With time, as the overstory matures and dies, the area can become denuded (A. Trame, pers. obs.). As occupation sites are abandoned and new areas become degraded, an increasing portion of the landscape provides less value for TES conservation, forestry, or realistic military training, unless rehabilitation is aggressively implemented.

Despite the severe consequences of occupation in some locations, it is possible for ongoing occupation activity to have little impact on soils or vegetation. One site on

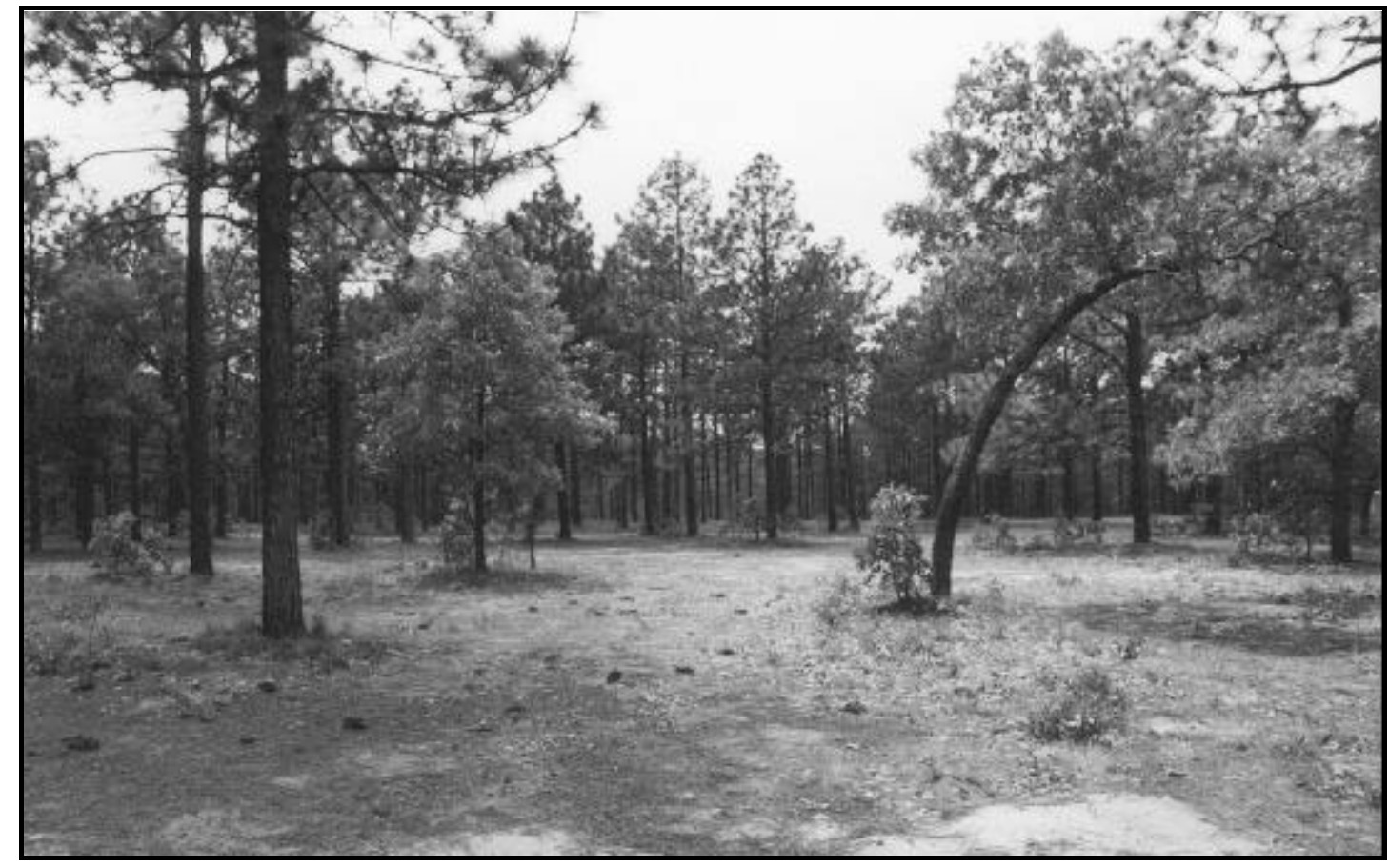

Figure 2. Damage to soils (compaction), groundcover, and overstory trees typical of areas used for intensive occupation exercises. 
Fort Bragg is used frequentGly but does not show permanent damage (A. Trame, pers. obs.). Although many areas within the occupation site are cleared of vegetation, there is no apparent erosion, and regeneration of longleaf pine is occurring in widespread islands of vegetation (F igure 3). Healthy stands of wiregrass grow immediately adjacent to places that receive concentrations of traffic (Figure 4). The plant community that supports this occupation site (drier sandhill community on flat terrain) appears to be fairly resilient tomilitary activities. More research may bewarranted to identify the factors that determine resiliencetolong-term and frequent occupation activity.

Recreational ORV use may be similar to off-road maneuver effects.

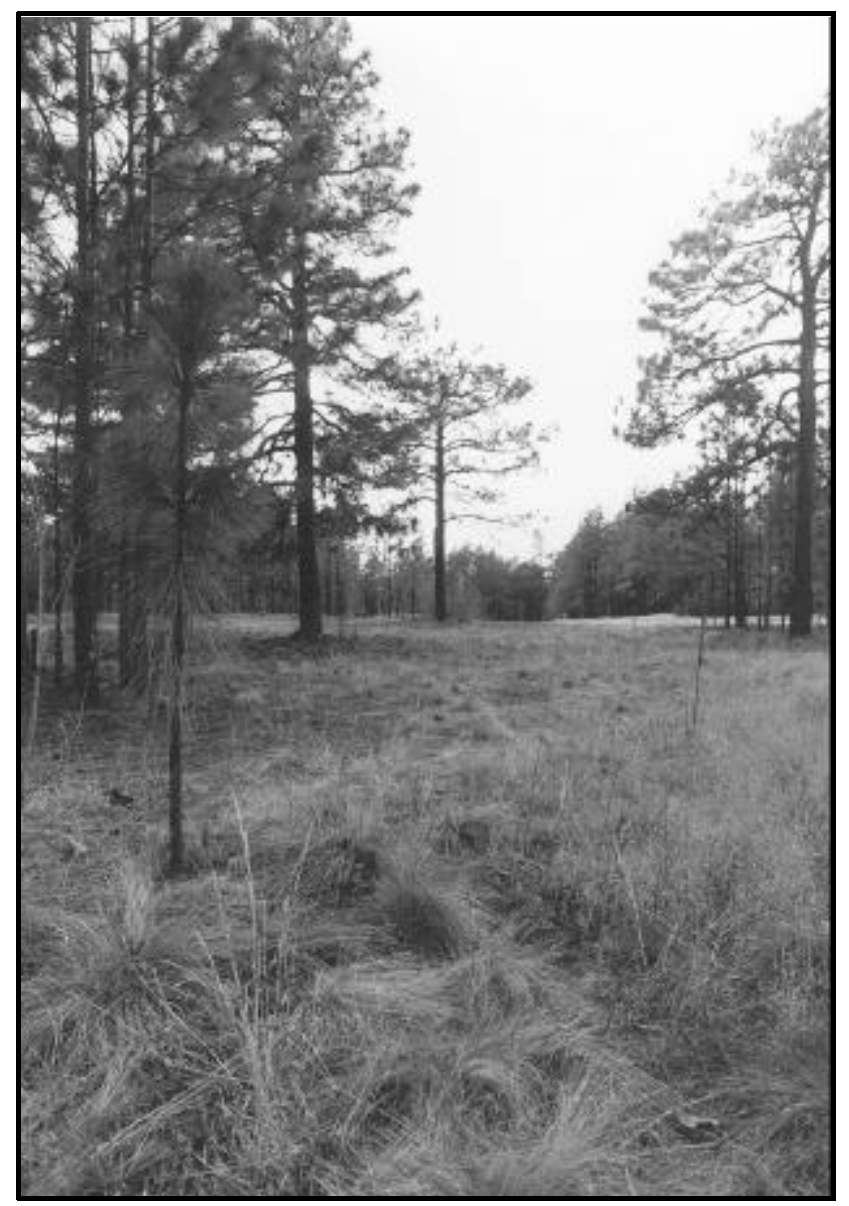

Figure 3. Although this occupation site has lost some vegetation, abundant longleaf pine regeneration can be seen in persistent forest islands.

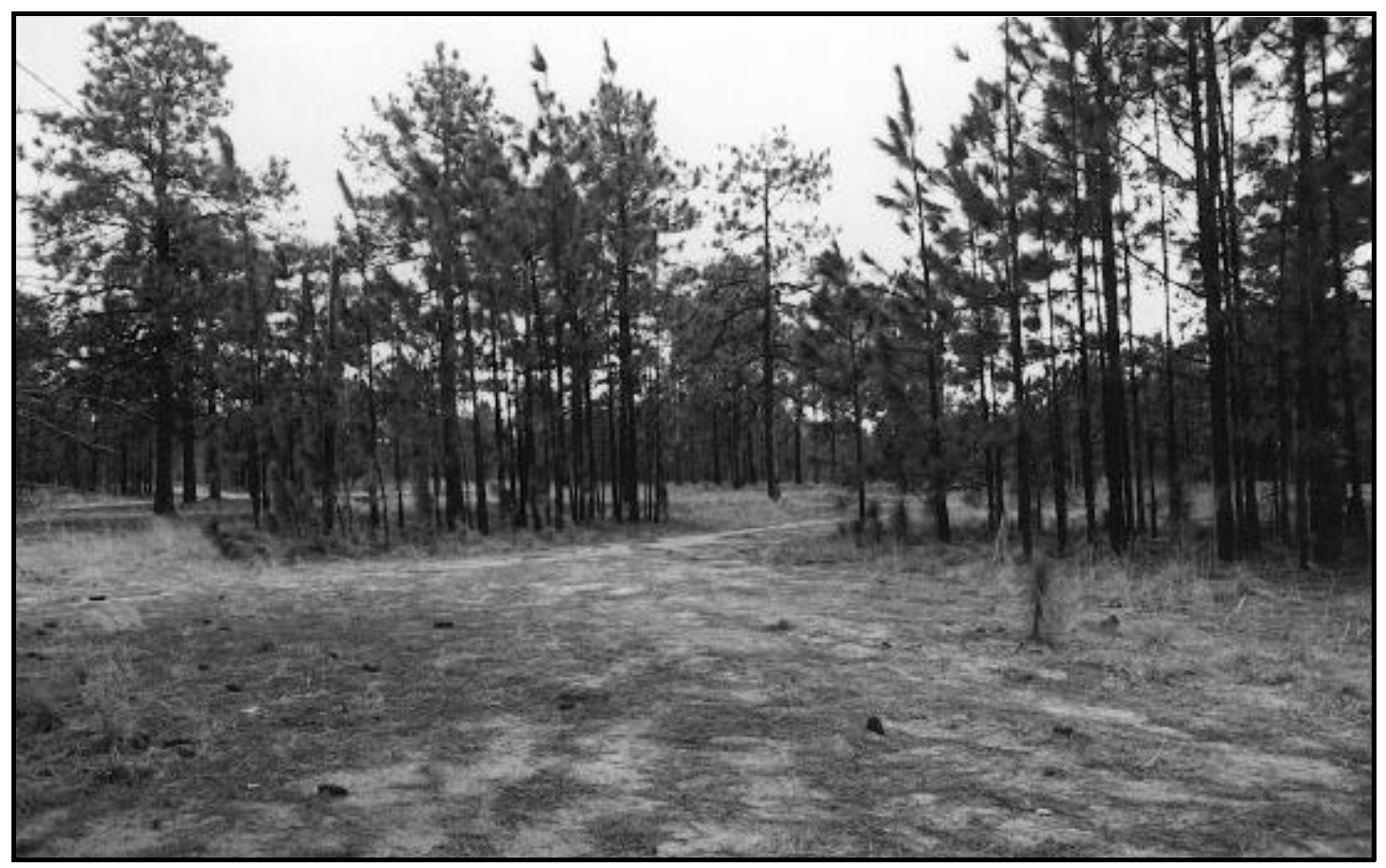

Figure 4. Wiregrass is still abundant near the edges of the occupation site. 
One study compared the effects of $1,10,100$, and 200 straight-line passes of motorcycles at a constant velocity in the Mojave Desert, CA. After one pass, the path was visible. After both 100 and 200 passes, berms formed al ong the path, and 10 to $30 \mathrm{~mm}$ of soil was displaced from the cycle track. Soil compaction was significant in all four treatments. Compaction was greatest immediately bel ow the soil surface. Higher speeds led to less compaction but greater soil displacement (Webb 1983).

The most applicable data on vehicle effects on soil compaction in the Southeast come from forestry literature. Foresters use tracked skidders and wheel ed trucks in harvest operations. However, it is not known how vehicle operator behavior differs in forestry operations compared to military exercises.

Effects of timber harvesting on soil compaction in the Southeast were reviewed by Reisinger, Simmons, and Pope (1988); soil compaction in general was reviewed by Greacen and Sands (1980). The foll lowing synthesis is from Harper et al. (in prep):

All harvesting activities cause some compaction, but the degree of compaction varies with equipment, techniques, intensity, and properties, especially moisture content and texture and vegetative cover (Reisinger et al. 1988; Aust et al. 1995). Most compaction occurs during the first few passes of a vehicle, and subsequent trips have little effect (reviews in Lockaby and Vidrine 1984; Reisinger et al. 1988). Moehring and Rawls (1970) and Greacen and Sands (1980) emphasized that more severe damage can occur from traffic on saturated soils compared to dry soils. For example, a tractor pulling three logs across dry soils removed soil litter, broke shallow roots, and scarified the soil surface. On wet soils, the sametreatment removed most of the litter, sealed and ponded the soil surface, broke large roots, and increased the shallow bulk density measurements by $13 \%$. In areas with few trees, deep gouges were created to a depth of 6-18" and deep roots were broken. (These wet soil impacts seemed to also increase the susceptibility of pine to black turpentine beetle attack; Moehring and Rawls 1970). Qualitatively different impacts and deeper disturbance profiles were also found by Aust et al. (1995) when they compared traffic on dry soils vs. wet soils. Susceptibility of soil to compaction is correlated with organic matter; soils with high organic matter content are more difficult to compact (reviewed in Greacen and Sands 1980). Similarly, soil type has a strong influence on susceptibility to compaction and subsequent recovery. On Mississippi steeplands, loamy surface soils over clay subsoils were most compacted by logging activities (Miller and Sirois 1986). In general, silt and clay soils compact more severely than sandy soils (Dickerson 1975).

Most field studies indicate that soil compaction lessens over time due to the combined effects of root activity, freeze/thaw cycles, and wet/dry cycles. Clay 
soils, which swell and shrink, may partially recover with wetting and drying cycles, but recovery of sandy soils, if any, is usually slower (Greacen and Sands 1980). Deeper layers of compacted soil take much longer to recover. Although the upper $8 \mathrm{~cm}$ of sandy loam and loamy sand soils recovered in 5-9 years, layers bel ow $8 \mathrm{~cm}$ took much longer and depths of $15-25 \mathrm{~cm}$ showed no signs of recovery (Thorud and Frissell 1976 in Reisinger, Simmons and Pope 1988). A study in an Atlantic Coastal Plain loblolly pine plantation showed that soils compacted on logging decks gradually recovered to prel ogged densities over an $18 \mathrm{yr}$ period (Hatchell et al. 1970), while Dickerson (1975) estimated a period of 12 years for Mississippi soils to recover normal bulk density and macropore values. (After 5 years, bulk density readings on logging roads were still high enough to interfere with pine species' survival and growth; Dickerson 1975). Tracks on sandy soils under pine forests in Australia, which had not been used for at least 50 years, were still compacted compared to surrounding soil (Greacen and Sands 1980).

Compacted sites drain more slowly, as shown by higher water tables and lower soil oxygen (Aust et al. 1995; Aust et al. 1993). Soil compaction can increase surface runoff due to reduced infiltration rates (Greacen and Sands 1980). However, runoff is affected by other factors, such as removal of vegetation (Greacen and Sands 1980). Soil compaction can lead to increased soil erosion when it increases runoff, but because compaction also increases soil strength, compacted soils may have lower erodability.

The effects of soil compaction on plant survival and growth are complex. Compaction alters soil strength, drainage, and aeration. Soil strength is a measure of its resistance to physical forces, including compaction and penetration by plant roots (Greacen and Sands 1980). Dry soils increase in soil strength as they become more dense, which reduces further compaction until eventually, no further compaction occurs (Greene and Stuart 1985). Wet soils have decreased strength compared to dry soils. Tree growth can be more limited in a dry year due to a combination of compression and water stress, while wet soils may not register any increase in strength so roots may continue to grow (Greacen and Sands 1980). This growth pattern has been seen in natural hardpans; roots can penetrate during wet seasons, but not during dry periods (Taylor and Burnett 1964). Conversely, wet compacted soils usually have lower oxygen available, decreased macropore space (which is the cumulative space within the soil structure that is critical to oxygen exchange for plants) and decreased hydraulic conductivity (Aust et al. 1993, 1995). These changes may then become the most important factors limiting root penetration and plant stress, especially on sites that naturally have good drainage and aeration (Aust et al. 1995). Other research shows that low oxygen may not be as critical as physical impedance: Taylor and Burnett (1964) and Day, Bassuk, and vanEs (1995) agree that soil strength is more important than decreased oxygen, 
while Gill and Miller (1956) caution that relatively moderate declines in oxygen become important only when combined with mechanical restraint.

One estimate calculates that bulk densities of $1.21 \mathrm{~g} / \mathrm{cm}^{3}$ and higher are restrictive to root growth, although this threshold varies with soil texture and plant species (Day, Bassuk, and vanEs 1995). For example, Lull (1959; cited in Kuss and Graefe 1985) states that root growth becomes restricted when bulk densities reach 1.4 $\mathrm{g} / \mathrm{cm}^{3}$ in fine textured soils and at $1.6 \mathrm{~g} / \mathrm{cm}^{3}$ in coarse textured soils.

\section{Community Perspective}

Coastal Plains soils may be wet, have little organic matter, and are sandy, with varying degrees of clay content. U pland soils havelower clay content and generally will experience less compaction from training activities. Flatwoods soils may have a greater chance of recovery from compaction because they experience wet/dry cycles and possibly swelling and shrinking as a result of higher clay content. This generalization requires more research becausethereareprobably other site-specific influences on compaction and recovery.

Wetlands. Any change to hydrologic regimes due to soil compaction is potentially a serious threat to wetland communities. Flatwoods sites often have a subsurface day hardpan that inherently has low hydraulic conductivity, thus lateral subsurface flow is important (Harper et al. in prep). In the flatwoods of the Francis Marion National Forest (SC), compaction from skid trails reduced lateral groundwater flow and dried one side of the study site (Aust et al. 1995). Such alterations would probably alter community composition and be detrimental torare species that are sensitive to changes in soil moisture.

Uplands. Upland soils with high sand content will not suffer a great deal of compaction. Even frequently used occupation sites may retain ground cover and pine regeneration if the soils are resistant to compaction (A. Trame, per. obs.). However, sandhill sites at Eglin Air Force Base, FL, showed signs of compaction al ong with extensive soil disturbance from past forestry operations. The compacted areas had the lowest plant species richness and greater densities of weedy species than apparently undisturbed sites (Provencher et al. 1996).

\section{Management}

Military training should beavoided in high quality areas harboring TES plants that have not been compacted previously, because soils are slow to recover from this disturbance. Activities to repair the effects of compaction (such as ripping or 
disking) would involve destruction of the groundcover, and these activities should not be allowed in natural communities where conservation of plant TES is important. It may be best to continue training in areas that have already been disturbed and compacted, for this will minimize the total area that eventually becomes damaged. In theseareas, restoration activities such as ripping and disking would be acceptable, as long as erosion could be mitigated.

Theuse of heavy vehicles should be avoided on wet sites that are desired for natural qualities (e.g., wetlands), and should beavoided during wet conditions (Greacen and Sands 1980), because these soils are more prone to compaction than are dry soils. Wet sites can be viewed as having a narrower window of time within which such activities can occur (Aust et al. 1995) without causing increased damage.

Management of frequently occupied areas or areas with high training use is needed to reduce damage and off-site impacts. Recreational camping literature has demonstrated that as much as 86 percent of the long-term damage to campsites can occur in the first $5 \mathrm{yr}$. Recovery of soils and vegetation takes decades (Cole 1987). When degradation occurs at a much faster ratethan recovery, rest-rotation systems (in which sites are used for a specified period of time and then rested for a period of time) are somewhat impractical. Thus, Cole $(1987,1995)$ and others have consistently recommended "confining camping to a small number of campsites instead of dispersing use across a large number of campsites." However, military occupation is substantially different than wilderness camping. Occupation impacts are largely caused by vehicle movement within woodland areas, so the rate of damage and the length of time that damage continues to affect soils are likely to be greater. Although a rest-rotation may not truly allow total recovery of military occupation sites, short rest periods to allow soil stabilization may justify shifting occupation activities to other sites. Otherwise, limiting the number of areas impacted by occupation activity is a worthwhilestrategy. Fort Pickett, VA, has reduced impacts to soils and partially protected islands of natural vegetation, including young trees and groundcover, by hardening (adding rock to) the most frequently used pathways within occupation sites (A. Trame, pers. obs.). Vehicle operators tend to use the hardened paths instead of bare soils, especially during wet periods (J . Proffitt).

\section{Effects on Fire Regime}

The most beneficial effect of military training activities in the southeast is the reintroduction of fire resulting from activities such as weapons firing and using incendiary devices. The frequency of ignition on military installations, especially in high hazard impact areas, often produces a fire regime over large areas at a 
frequency that resembles presettlement natural fire return intervals. This regime encourages a mosaic burn pattern and enhances conditions for fire-adapted species (Gulf Engineers and Consultants, I nc. and Geo-Marine 1994; LeBlond, F ussell, and Braswell 1994a; A. Weakley; R. Stewart, Botanist, Kisatchie National Forest, professional discussion, 24J uly 1995). For moreinformation, Harper et al. (in prep) reviews (1) southeastern fire ecology, (2) how land uses influence the current fire regime on military installations, and (3) recommendations for fire management to conserve TES.

Military training can impact native communities and TES by fragmenting the fuel sources needed to carry fire over large areas. Native groundcover, especially grasses, are essential fuel sources that allow large areas to burn. Bunchgrasses are often eliminated in occupation sites, assembly areas, and maneuver areas through direct destruction or soil compaction. Areas that do not burn undergo a change in species composition, sites become increasingly shaded through time, and the natural community (and TES habitat) is ultimately lost. For example, suppression of growing season burns may favor loblolly pine and hardwoods over longleaf and slash pines (USFS representative; Harper et al. in prep). No known study has examined the spatial distribution or rate of groundcover removal and resulting fire suppression, but the observations of field biologists suggest a direct relationship. Very intensive use may lead to large areas without ground cover (Figure 5; R. Stewart, 9 May 1995). Pine straw will carry fire, but the effect is diminished compared with burning native bunch grasses (E. Stewart, Biologist, Kisatchie National Forest, LA, professional discussion, 9 May 1995).

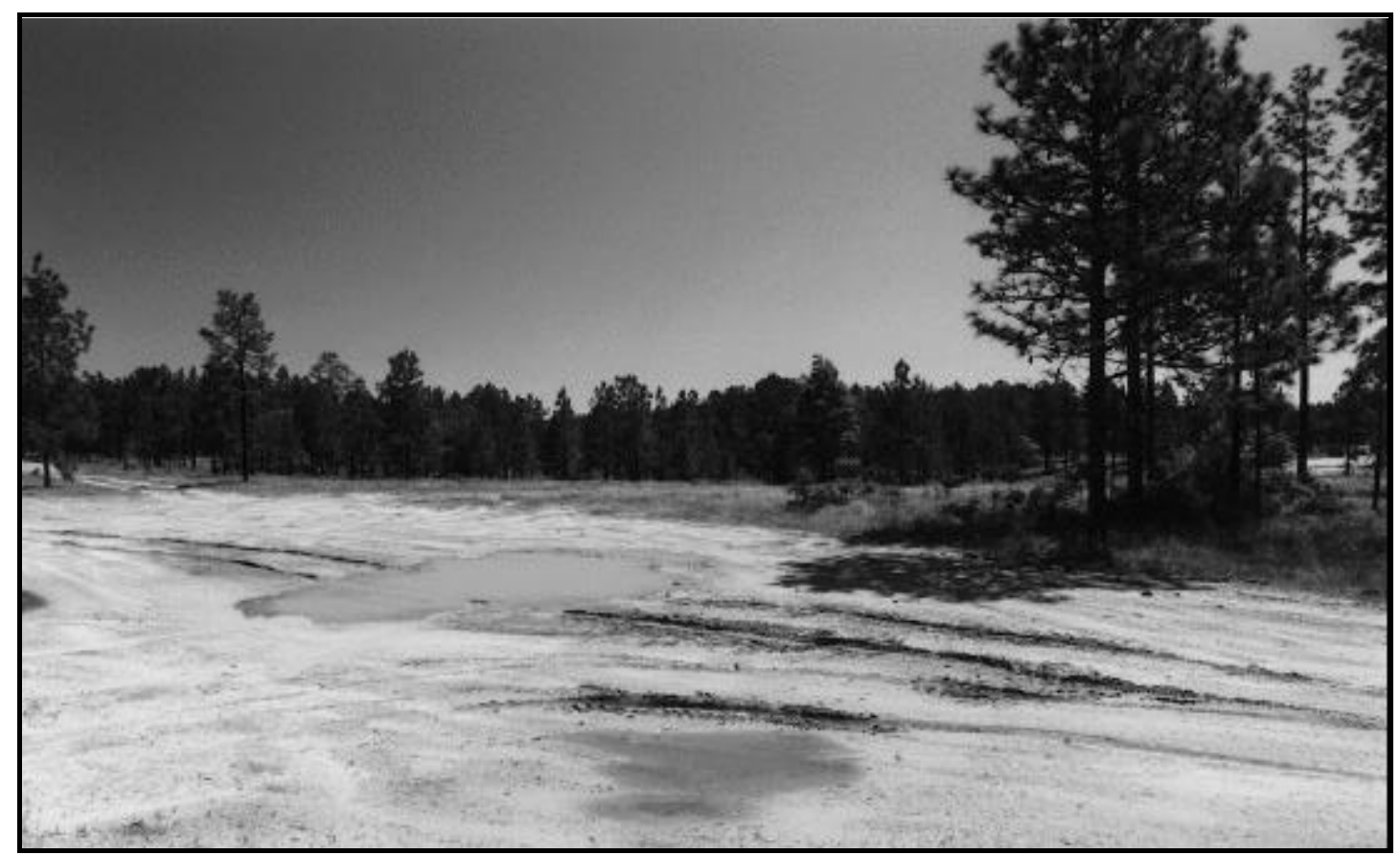

Figure 5. Assembly areas and tank maneuver sites become barren, which fragments fuel sources and prevents fire from carrying over large areas. 
Another potential concern on military lands is that burning may not be possible because troops are present in the field. Coordination between range control personnel and prescribed burn teams would improve the chances that proper burns are conducted as needed for TES requirements without limiting the ability of military units totrain. The magnitude of this impact varies from installation to installation. It may be a greater problem where communication and staff are more limited, or in cases where weather patterns restrict opportunities for prescribed burns.

\section{Direct Damage to Vegetation}

The damage to ground cover and other plant species by movement and occupation exercises may be comparable to that caused by recreational activities such as ORV use, hiking, and camping. Most available information comes from recreational studies outside the southeastern region. In these studies, trampling injury to plants by recreationists caused damagesimilar to nutritional or diseasestress, such as abnormal cellular activity and impaired root formation, photosynthesis, respiration, and energy metabolism (reviewed in Kuss and Graefe 1985). A reduction in growth, vigor, and reproduction are common impacts (Kuss and Graefe 1985, Cole 1987).

Sustained high levels of trampling can ultimately eliminate vegetation. Trumbull et al . (1994) documented a 57 percent decrease in woody stem density, a 72 percent decrease in understory cover, and an increase in bare ground (17 percent cover vs. 2 percent) in intensively used occupation sites at F ort Leonard Wood, MO. Canopy cover was reduced for height classes of 0.6 tol.0 $\mathrm{m}$ (Trumbull et al. 1994). J ames et al. (1979) documented the loss of all vegetation except mature trees in northwestern Ontario. Garton, Hall, and Foin (1977) found a decrease in plant abundance for plants less than 7.6-m tall, loss of foliage under 6.1-m high, and a 49 percent increase in bare soil as a result of recreational camping in California. Blakesley and Reese (1988) found lower shrub, sapling, and tree densities in campground sites vs. noncampground sites in northern Utah. Based on these findings, it is likely that intensive nonmechanized military training and recreational activities in the Southeast would also lead to reductions in ground cover and possibly reduced pine regeneration. In general, reductions in plant heights, species richness, and cover are greatest in the core area of a campsite, and thus are localized impacts (Cole 1987).

Trampling from recreation or military training can alter soil characteristics, which leads to population declines of native plants, simplification of vegetation, and loss of habitat diversity for theanimals that rely on those plants (reviewed in Boyleand 
Sampson 1985). Harsh soil conditions favor species tolerant of moistureand oxygen stress. Early successional species, very sturdy species, and disturbance-adapted species are favored, leading to changes in community composition and structure (McDonnell 1981, Cole 1987, Tazik et al. 1992) such that native species richness and species diversity decline (Cole and Landres 1995). In general, grasses and sedges are more resistant to damage, while low shrubs, tree seedlings, and lichens are very susceptible (Cole 1987).

Trampling can also affect the plant community near frequently used footpaths. Within 1 to $2 \mathrm{~m}$ of the edge of the trail, the plant community is altered. Some species, especially those adapted to the forest floor, are eliminated, while disturbance-tolerant and trampling-tolerant species increase. Some species invade the areas near, but not immediately adjacent to, trails. Beyond this 1- to 2-m trail border, minimal effects on native vegetation were observed (Dale and Weaver 1974).

Most research on mechanized training impacts has been conducted in the western United States (reviewed in Guertin 1995; Trame 1977). Available research has shown that most damage occurs from off-road movement (Michigan Department of Military Affairs [DMA] 1994). Direct impacts to soil characteristics-including altered oxygen, water, and nutrient content-and changes to $\mathrm{pH}$ and infiltration rate lead to reductions in germination, growth, and reproduction in native plants (Cole and Landres 1995) and changes in species composition and community structure (Beije 1987; Cole and Landres 1995). These findings are consistent with those from a study on Fort Benning, GA, where sandy ridges in the longleaf pine/turkey oak community subjected to tracked vehicle use now resemble old field successional areas, and frequently used areas are completely barren (Goran, Radke, and Severinghaus 1983).

On Fort Polk, LA, the following observations were made: (1) areas of bare ground, without seedlings, were criss-crossed by vehicle tracks and scarred by vehicle-dug pits, (2) a reduction in vegetation at the ground, shrub, and tree levels, (3) trees bent, twisted, and scarred by direct vehicle impact, (4) trees fallen or standing dead or partially dead, apparently because of root damage caused by repeated vehicle passings near them. Researchers also measured fewer trees in mechanized training areas compared to control areas (100.5 trees/ha vs. 193 trees/ha), although tree growth in training areas was higher $(7.4 \mathrm{~mm} / \mathrm{yr}$ vs. $6.0 \mathrm{~mm} / \mathrm{yr})$. (Goran, Radke, and Severinghaus 1983).

In the absence of extensivestudies on military activities, comparisons can be made with known impacts of mechanical logging and site preparation activities, which are 
reviewed in Harper et al. (in prep). In particular, soil disruption and direct destruction of shallow-rooted ground cover species lead to domination by winter annuals and agricultural grasses (DA 1994) and a general decrease in diversity of theherb layer (Hart and Lester 1993). Potential impacts from mechanized training are discussed below on a community basis. 


\section{Potential for Disturbances in Selected Plant Communities}

Military training has the potential to affect plant communities through trampling of vegetation, disturbance of the soil surface, and changes to hydrologic patterns. The potential for such impacts due to military training is discussed bel ow for some of the more significant plant communities in the Southeast. Much of the information provided is from expert opinion or taken from installation reports that address community impacts and management for military lands.

\section{Longleaf Pine Woodlands}

\section{General Description}

This community is fairly resilient to transient foot traffic and low to mid-intensity mechanized maneuvers (DA 1994; Gulf Engineers and Consultants, Inc. and GeoMarine, Inc. 1994). The plants of these communities are adapted to periodic loss of their aboveground parts, so they can recover from periodic trampling. Similarly, the direct impacts from low-intensity, individual vehicle ruts are not significantly detrimental, unless creation of ruts is frequent and extensive enough to lead to gully erosion (A. Weakley). This effect depends on the hydrology of the location-drier sites can withstand more intensive training activities than wetter communities. Similarly, the community will be more sensitive to damage during wet seasons (March through J une and October through November) compared to drier seasons (December through February and J uly through September; R. Stewart, 9 May 1995).

Intense use of tactical land vehicles (both tracked and wheeled) can cause extensive soil disturbance. In flatwoods, this can lead to ponded areas and restricted subsurface water flow. Figure 6 shows an area where off-road tank traffic has led toruts, ponding, firesuppression, and consequential changes in thecomposition and structure of the flatwoods community. Ruts provide new microenvironments that aredrier or wetter than the natural moisture level, which may allow invasion of the community by plants that otherwise would not occur. In sandy uplands, ruts can 


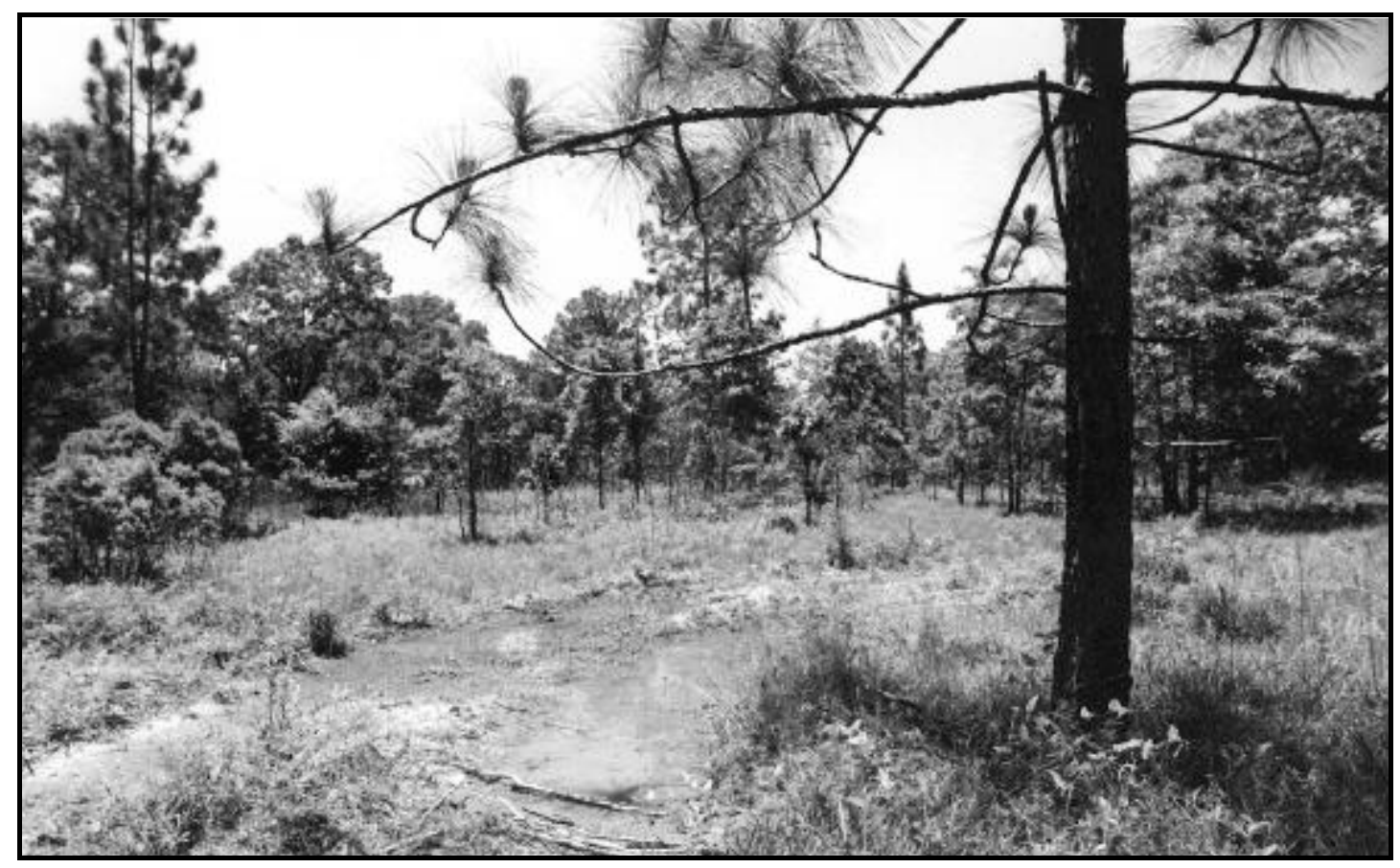

Figure 6. Off-road tank traffic in flatwoods community led to rutting, ponding, fire suppression, and consequential changes in the composition and structure of the community.

lead to gully formation and channeling of both water and nutrients away from the community, usually into lower areas such as streambeds (Russo et al. 1993). O'N eil et al. (1990) predicted rutting depths in soils at Yakima Training Center, WA, under four military force training levels, and identified three threshold levels of training intensity. Unfortunately, this type of information is not available for locations in the Southeast. At some (unknown) level of intensity, soil disturbances and altered hydrology will significantly alter the community structure and composition, and these impacts will remain until normal water flow is restored (LeBlond, F ussell, and Braswell 1994a). These impacts can be serious for wet pine woodland communities. Prescribed burning alone cannot maintain these communities if the water flow is channelled away through ditching and rutting (FNAI 1994).

Mechanized movement damages native plants (Outcalt and Lewis 1990) and reduces the potential for plant re-establishment. Combined with soil disturbances, these conditions favor winter annuals and agricultural grasses over native groundcover (DA 1994) and can decrease the diversity of the herb layer (Hart and Lester 1993). Tactical maneuver training and digging activities mix soil horizons (LeBlond, F ussell, and Braswell 1994b, F NAI 1994), which further encourages invasion of the community by non-native species. The understory of most pine woodlands in the Southeast serves a keystonefunction in maintaining theentirecommunity by facilitating growing season burns (Noss 1989; see Harper et al. in prep for 
a review of impacts to native grasses and restoration information). Once the bunch grasses are removed, fire can no longer spread throughout the community, and a dense understory will prevail. However, some early-successional, native ground cover species show regrowth when bare sites in occupation areas are rested (A. Trame, M. Harper, pers. obs.). The conditions that influence community recovery are not well understood and require further examination (Duever 1989).

\section{Plant TES Species}

The following woodlands species were assessed by J ordan, Wheaton, and Weiher (1995) for their sensitivity to harm from various military activities:

American chaffseed (Schwal bea americana)

Michaux's sumac (Rhus michauxii)

Carolina goldenrod (Solidago pulchra)

rough-leaved loosestrife (Lysimachia asperulaefolia)

Carolina grass-of-Parnassus (Parnassia caroliniana)

sandhill's milk-vetch (Astragalus michauxii)

Eulophia (Eulophia ecristata)

smooth bog-asphodel (Tofielda glabra)

Georgia lead-plant (Amorpha georgiana var. georgiana)

spring flowering gol denrod (Sol idago verna)

incised groovebur (Agrimonia incisa)

Well's pixie-moss (Pyxidanthera barbulata var brevifolia)

While on-road vehicletraffic, artillery and small arms firing, and the use of smokes and obscurants is not thought to harm these species, ORV traffic can be potentially detrimental (J ordan, Wheaton, and Weiher 1995). Threats were described as "ditching and draining," "changes to hydrol ogy," and "trampling" (V ordan, Wheaton, and Weiher 1995). Russo et al. (1993) also listed direct physical destruction and ground disturbanceas threats to populations of American chaffseed, Carolina grassof-Parnassus, and smooth bog-asphodel.

\section{Bottomland Hardwoods and Deepwater Swamps}

Bottomland hardwood and deepwater swamp communities (also called alluvial forests) generally are not utilized for mechanized military activities because of the high density of large trees, mucky soils, and concerns for water quality management. It is likely that a tracked vehicle would not be successful in crossing even a narrow band of floodplain or deepwater swamp, so these communities usually are 
avoided by mechanized troops and do not experience the soil disturbances and loss of vegetation that mechanized activity can produce (J . Nelson, Botanist, U niversity of South Carolina, professional discussion, 10 May 1995; B. Pittman, Community Ecologist, South Carolina Natural Heritage Program, professional discussion, 10 May 1995; R. Stewart, 9 May 1995; M. MacRoberts; B. MacRoberts, Botanist, Bog Research, professional discussion, 24 J uly 1995). However, if mechanized activity did occur in such a way to alter flow regime, sediment load, vegetation patterns, or groundwater levels, it could have a significant impact on the alluvial forest (Ward 1989).

The hydroperiod (flooding regime) refers to the frequency, depth, and duration of flood events. These factors are the driving forces that structure all uvial forests and control ecosystem functions (Gosselink et al. 1990). The hydroperiod is influenced by climate, topography, channel slope, soil characteristics (Gosselink et al. 1990), and groundwater fluctuations (Patrick et al. 1981). The hydroperiod can bealtered through clearing of vegetation on uplands (e.g., clearcutting or agricultural conversion). After clearing, the increased runoff from the upland leads to higher frequencies and intensities of flood pulses. Any activity that affects water flow in the watershed may affect the hydrology of the associated bottomland ecosystem (Harris and Gosselink 1990).

Such changes in the hydroperiod will affect sedimentation on the floodplain and in the stream. The topography of the floodplain, natural ponding areas or sloughs, downed wood, vegetation, and other sources of surface heterogeneity contribute to sediment retention. Activities that modify or flatten the terrain, such as agricultural conversion, will often increase sedimentation in streams (Scott et al. 1990). If activities such as mechanized maneuvers remove vegetation and leave unstable, rutted soils, these soils will likely erode into the streams during flood events.

Flooding patterns are linked to soil characteristics such as aeration, water holding capacity, and nutrient exchange dynamics. Oxygen levels in the soil are controlled by the rate at which excess water drains from the surface through the soil profile, which is related to soil characteristics such as clay content and distribution. Soil aeration is a major determinant of community composition and species distributions because it affects oxygen, water, and mineral absorption by roots (Harms 1973). In general, an air-filled volume of 15 to 20 percent of the total soil volume is needed to support a diverse bottomland community (Patrick 1981).

Bottomland vegetation is influenced in part by thetiming, frequency, and duration of anaerobic conditions due to flooding (Hosner 1958; Huffman and Forsythe 1981). Individual tree species have different tolerances to drought, saturated soils, and 
water depth (e.g., Dickson and Broyer 1972; Young, Keeland, and Sharitz 1995). A study of three Louisiana swamps showed differences in community composition and recruitment due to differences in flood regime. One swamp had variable, natural flooding; a second was permanently inundated; and the third was managed for crawfish (Procambarus spp.; flooded to a depth of $40 \mathrm{~cm}$ in the fall and drained from J une to August). The natural area maintained a high quality plant community, dominated by bald cypress (Taxodium distichum) and water tupelo (Nyssa aquatica) with the occasional willow (Salix spp.), ash (F raxinus spp.), and red maple (Acer rubrum), with a basal area of 94 . The most common trees on the crawfish farm were red maple and ash (basal area 39), although large tupelo and bald cypress (basal area 50) were also present. The permanently flooded area had the fewest cypress and tupelo trees, the lowest basal area (63), and high densities of button bush (Cephalanthus occidental is), red maple, and snowbell (Styrax spp.) due to the open canopy. Ash trees had previously dominated the community, but had died after the flooding regimechanged (Conner, Gosselink, and Parrondo 1981).

The river floodplain is an open system that is sensitive to events upstream and in adjacent uplands. Activities in adjacent uplands tend to affect small streamside communities more than large bottomlands. Erosion from sandy uplands as a result of drop zone creation, off-road mechanized maneuvers, or occupation exercises may lead to significant sedimentation in smaller streams and bury sensitive wetland plants (A. Trame, pers. obs.). Changes to groundwater flow may be less visible but potentially could impact TES plants just as severely. Many bottomland hardwood communities exist on alluvial deposits underlain by older permeable strata, which creates a shallow aquifer. Changes in infiltration, percolation, lateral seepage, or subsurface channelized flow due to deep ruts or gully erosion could be damaging to sensitive plant species (Malac et al. 1981).

Alluvial forests can sustain soil impacts from orienteering or cross-country marches. Yorks, West, and Mueller (1993) hypothesized that floodplain species' adaptation to saturated, low-oxygen soil conditions may make them more resilient to stress caused by soil compaction from human activities. However, the understory vegetation may be less resilient to aboveground structural damage than fireadapted upland species.

Alluvial forest understory plants can bestrongly associated with specific hydrol ogic conditions and, thus, be very sensitive to changes in hydrology (K ovacic et al. 1989; LeBlond, Fussell, and Braswell 1994b). Any activity that creates erosion from uplands or changes soil moisture conditions will threaten TES in floodplain areas. Threats to Chapman's sedge (Carex chapmanii), southern lady's slipper (Cypri pedium kentuckiense), and hairy-peduncled beaked rush (Rhyncospora crinipes) 
included disturbances to soil and hydrology associated with logging activities, vehicle activity, stream crossings, and upslope military training (Hart and Lester 1993; LeBlond, Fussell, and Braswell 1994b; J ordan, Wheaton, and Weiher 1995). These studies support the hypothesis that mechanized military training would threaten understory TES if it occurred in or directly adjacent to alluvial forests.

\section{Inclusional Wetlands}

\section{General Description}

Small but ecologically important wetland communities are found throughout the larger longleaf pine communities in the Southeast. These include (1) herbdominated communities associated with seeps, (2) herb-dominated depressed open areas with perched water table (reviewed in Harper and Trame in prep), (3) shrubdominated streamhead pocosins or baygalls, and (4) cypress savannahs (reviewed in Robertson in prep). Occurrences of these communities are generally small and isol ated in thelandscape, making them very sensitiveto processes and disturbances that occur in the nearby uplands. Ecotones between the larger longleaf pine woodlands and theseinclusional wetlands providecritical environmental conditions required by many plant and animal TES species in the Southeast; therefore, these areas deserve proper protection and management.

Inclusional communities depend on a natural fire regime, which maintains an open canopy and unaltered groundwater flow (reviewed in Harper and Tramein prep and Robertson in prep). Hot, frequent, military-ignited fires are highly beneficial for these communities. The relative frequency and intensity of fire over time creates a dynamic relationship between streamhead pocosin vegetation, the surrounding seepage bog, and the ecotone with the upland. After a hot burn, the bog will expand into the upland and towards the stream. After a period of time without intensefire, the bog contracts in size and the pocosin species expand outward (R. Stewart, 24 J uly 1995).

Littleis known about the effects of soil disturbance on hundreds of wetlands species (F rost, Walker, and Peet 1986). Low intensity, nonmechanized activities, such as troop movements on foot, are not known to have significant positive or negative impacts. The plants that occur in these inclusional communities are adapted to periodic loss of their aboveground parts from fire, and they can recover from light, periodic trampling (R. Stewart, 9 May 1995). Tactical land vehicle use causes alterations in hydrology in this community, and this appears to be an unavoidable negative effect. A healthy, natural bog community cannot sustain any vehicle 
disturbance at all, regardless of time of year (LeBlond, Fussell, and Braswell 1994b). Ruts formed by vehicles will pool water, and can support more hydrophytic species than naturally would occur; the wheel ridges are drier than normal, so they provide sites for invasion by more xerophytic species (Frost, Walker, and Peet 1986). E ven one pass of a tank will create deep enough rutting to divert the natural overland water flow into a narrow channel, drying out the surrounding areas ( $R$. Stewart, 9 May 1995; A. Trame, M. Harper, per. obs.; Figure 7).

Alteration of hydrology can occur on flat areas, gentle slopes, and steeply sloped terrain. In flat areas (such as wet areas that are imbedded in flatwoods), erosion and channeling of water will not occur across very large distances, thus the effect will be localized. However, on steeper terrain associated with hillside seeps or streamhead pocosins, gullys that begin along distant roadways and tank trails on ridgetops can channel water away from an entire hillside. In thesecases, the whole drainage is involved, which poses a landscape-level problem (A. Trame, M. Harper, per. obs.).

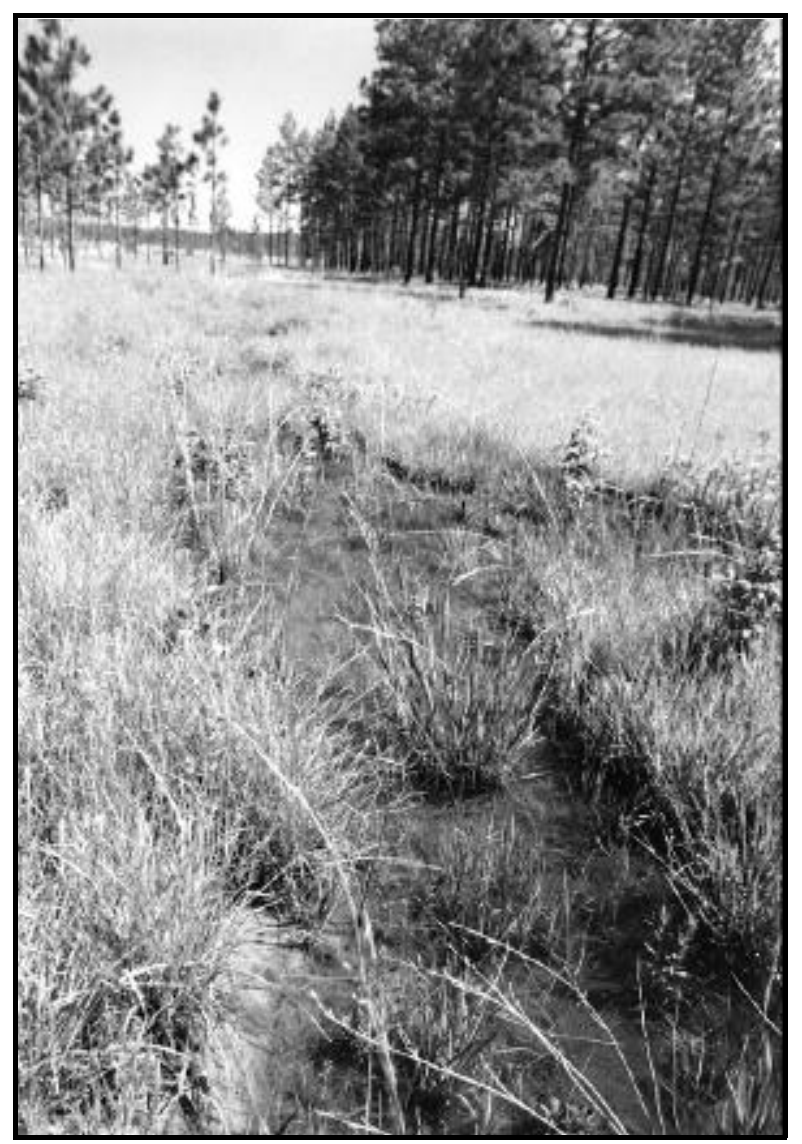

Figure 7. Tank traffic through a bog left deep ruts, which fill with water and channel overland water flowCpitcher plants (Sarracenia spp.) no longer grow along the ruts because the soil is too dry.
Even relatively minor ruts will persist in a wetland community, possibly for decades (M. MacRoberts). Mechanized traffic can alter the underlying hardpan layer as well, which would allow the soil to dry out, making it uninhabitable for wetland species (FNAI and TNC 1995). Long-term tank maneuvers can lead to almost total conversion of an herb bog community as early successional, upland species such as wax myrtle (Myrica cerifera) and St. John's Wort (Hypericum spp.) invade (Figure 8). Once this occurs, frequent fires will not be adequate to restore the community (FNAl 1994). The lowestIying areas can pond water and create an inappropriate habitat for marsh species such as button bush, cattails (Typha latifolia), and marsh panic grasses (Panicum spp.; A. Trame, per. obs.). After moderate to high levels of tank training, the community may be 


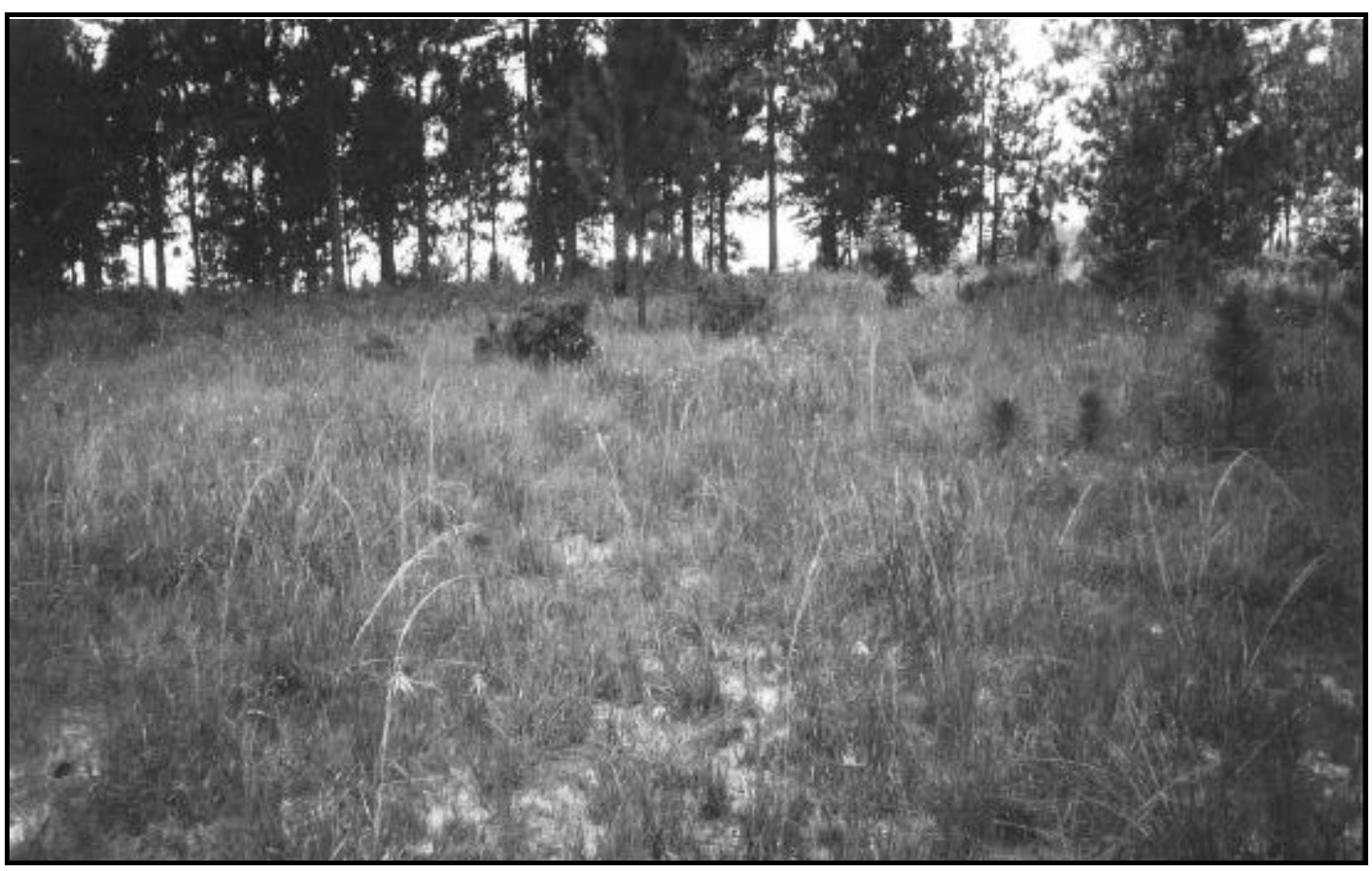

Figure 8. A bog drained by tank ruts is now dominated by wax myrtle and St. John's WortC deep ruts remain under the vegetation.

destroyed to such an extent that restoration becomes impossible or prohibitively expensive (M. MacRoberts; B. MacRoberts; Figures 9 and 10). Thus, it is likely that healthy inclusional wetland communities and mechanized vehicle training are incompatible in the southeastern United States (LeBlond, Fussell, and Braswell 1994b).

\section{Plant TES Species}

The following wetland species were assessed by J ordan, Wheaton, and Weiher (1995) for their sensitivity to harm from various military activities:

\section{American chaffseed}

pine barrens boneset (Eupatorium resinosum)

bog spicebush (Lindera subcoriacea)

purple balduina (Balduina atropurpurea)

Carolina grass-of-Parnassus

rough-leaved loosestrife

Carolina goldenrod

smooth bog-asphodel

Eulophia

spring flowering goldenrod

hairy-peduncled beaked-rush (R hynchospora crinipes)

Venus' Fly-trap (Dionea muscipula) 


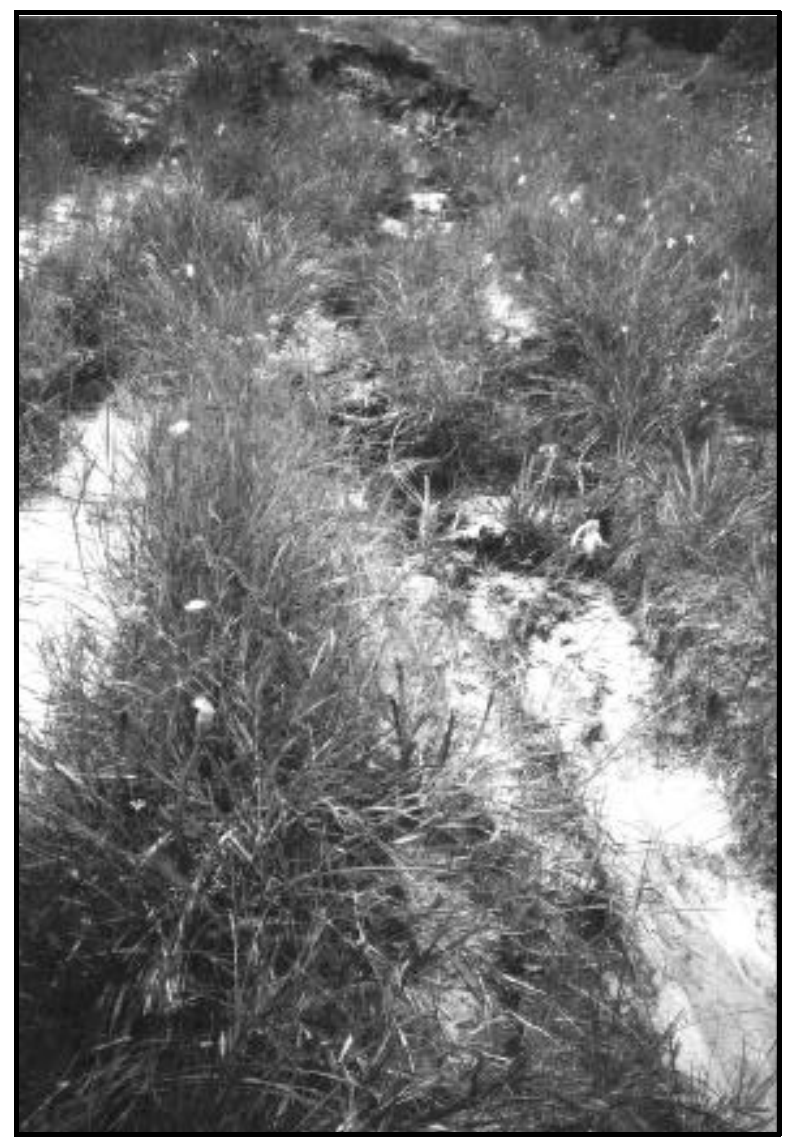

Figure 9. A bog that recently became an off-road tank maneuver site shows bog species persist near deep ruts that are channeling water and soils downslope.
Harper's yellow-eyed grass (Xyris scabrifolia)

whicky (Kalmia cuneata)

panhandle lily (Lillium iridollae) While on-road vehicle traffic, artillery practice, small arms ranges, and the use of smokes and obscurants should not harm these species, ORV traffic potentially can be detrimental (J ordan, Wheaton, and Weiher 1995). Threats were described as "ditching and draining," "changes to hydrol ogy," "drying of habitat," "soil compaction," and "trampling" (J ordan, Wheaton, and Weiher 1995). Russo et al. (1993) also listed direct physical destruction and ground disturbance as threats to populations of American chaffseed, Carolina grass-of-Parnassus, and

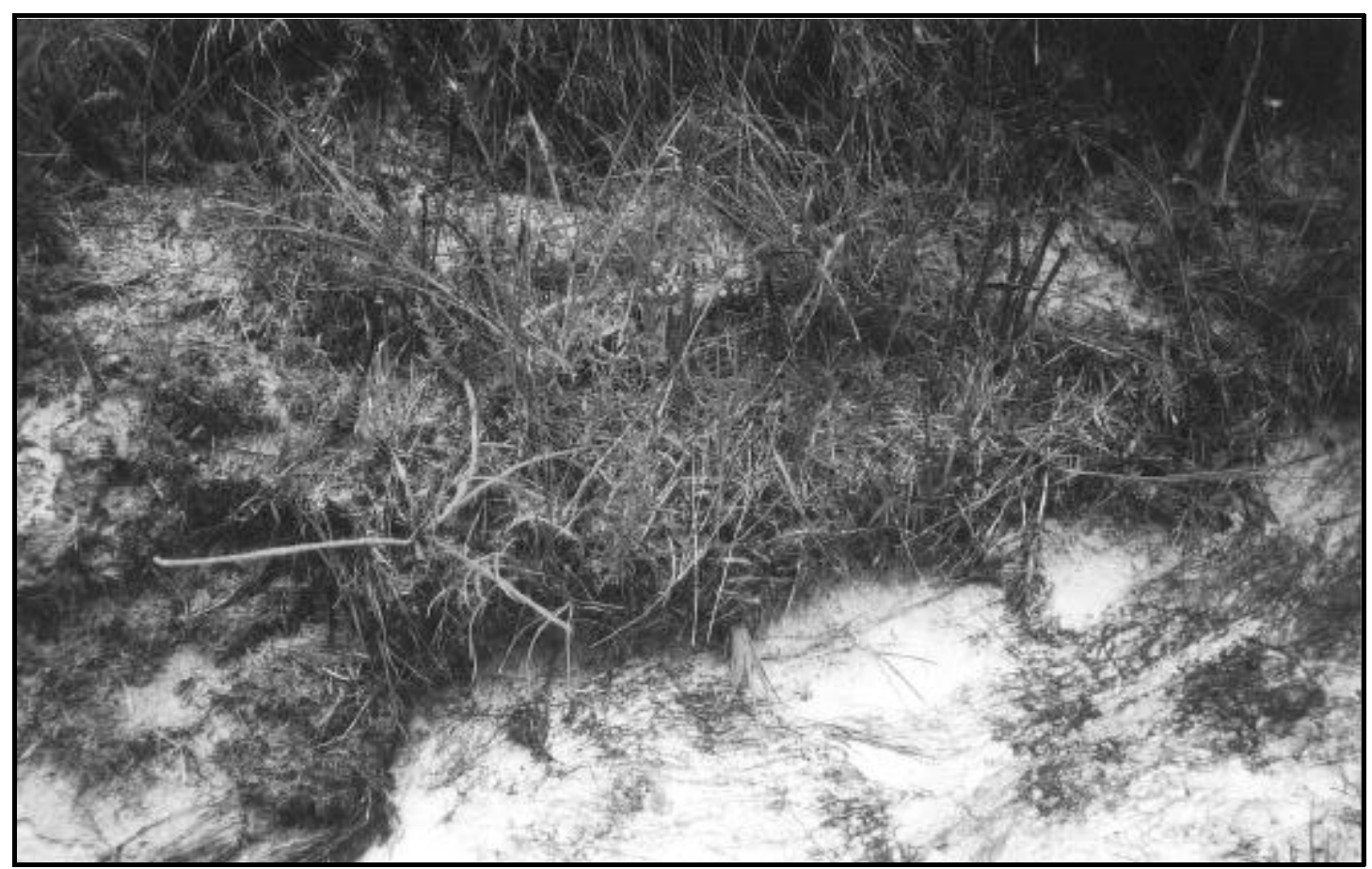

Figure 10. This bog area appears to be irrepairably harmed after only a short period of use. 
smooth bog-asphodel. Drainage of habitat is the most significant threat to Chapman's rhododendron (Rhododendron chapmanii) due to its narrow tolerance of moisture levels (USFWS 1983). 


\section{Management of Natural Plant Communities for TES Conservation}

This report recommends management that promotes the conservation of TES habitat sites and does not intend for application to be made across entire DoD installations. In some cases, these recommendations may appear to conflict with thetop priority of the military training mission. However, themilitary mission and TES habitat are not mutually exclusive. By managing for robust TES populations, installations may benefit from fewer restrictions on land use as a result of theESA. Installation training and natural resources personnel are constantly challenged to reconcile the needs of TES with the requirements of the military mission. The following recommendations are given to assist in this regard, by providing current information about TES habitat needs.

Recent focus on red-cockaded woodpecker (RCW) management has led to an increase in land area burned by prescribed and mission-related fires, and has increased the quality of plant communities all across DoD lands in the Southeast. This application has benefited numerous plant and animal TES and other taxa that depend on RCW and adjacent habitats. An increased focus on hydrologic impacts would move DoD towards moreintegrated TES and natural resources management and would assist decisionmakers in reducing the impacts of intensive training.

\section{Management of High Quality, Sensitive, and Rare Communities for TES}

Limited areas, such as inclusional wetlands and high quality sites that harbor TES, should be protected from negative impacts such as erosion, sedimentation, compaction, firesuppression, and intensivetrampling or ground disturbance. These areas should not be used for any mechanized training, including occupation exercises that involve vehicles (Russo et al. 1993; LeBlond, Fussell, and Braswell 1994a). A buffer zone of protection should extend well across ecotones to prevent sedimentation into wetlands, fire suppression due to loss of fuels, or changes to hydrology of wetlands and uplands. Harper and Trame (in prep) recommended a buffer boundary of at least $61 \mathrm{~m}$ on slightly sloping lands or $30.5 \mathrm{~m}$ on flat terrain. For hillside seeps or streamhead pocosins in hilly areas, the immediate drainage 
should be protected from the top of the slope to the drain below the bog, since recharge and discharge patterns are critical for wetland conservation (Harper and Trame in prep). Traffic on nearby dirt roads or trails in adjacent areas should be minimized. If traffic does occur, the road should be monitored carefully for erosion ( ordan, Wheaton, and Weiher 1995). However, even rare, high quality, and wetland communities that are fire adapted can sustain reasonable levels of nonmechanized military use, as long as digging is not involved.

\section{Longleaf Pine Woodlands}

Longleaf pine woodlands greatly benefit from frequent fires ignited by munitions training and testing. Mission-related fires should be allowed to burn across the landscape as much as possible. When planning activities with a goal of minimizing impacts to TES habitat, drier flatwoods and sandhills should be sel ected over wetter flatwoods for any kind of mechanized movement. This selection will reducedamage from soil compaction, rutting, and channeling of water flow. Low impact uses, such as transient foot traffic or low intensity vehicle use, are compatible with most TES plants and animals, unless species are experiencing the stress of the breeding season or extremely harsh weather.

Intensive occupation exercises should be planned for fewer sites that are permanently altered and used, rather than many sites that are used in restrecovery rotation. The recovery phase probably will not be long enough to allow regeneration of the natural community (A. Weakley, Cole 1995). When additional occupation or maneuver trainingsites areplanned, fragmentation of thecommunity should be minimized, so that landscape-level hydrologic processes and fire regimes are less disrupted (Hart and Lester 1993). Lower quality communities should be considered for conversion to multipurpose ranges, drop zones, or intensive mechanized maneuver zones. Higher quality sites can be utilized for less damaging activities such as transient nonmechanized maneuvers. Large, homogenous, flat areas should be favored for training over areas that are bisected by streams and inclusional wetlands, when possible.

While erosion control measures are beneficial to the pine woodlands communities and associated species, the use of invasive exotic species should be avoided; whenever possible, native species should be re-established. In flatwoods, it is also important to preserve the original contours of the land to maintain the proper hydrologic patterns (J ordan, Wheaton, and Weiher 1995). 


\section{Bottomland Hardwoods and Deepwater Swamps}

It is important to capture any sediment in runoff from uplands, before it is deposited on the floodplain, to maintain the integrity of alluvial forest communities and to protect stream quality (Hart and Lester 1993). This maintenance is particularly important for small streams that are tightly linked to processes occurring in the sandhills community. A buffer zone around small high quality streams will reduce sedimentation and should reduce changes in groundwater flow from uplands as well. In hilly areas, it may be necessary to avoid vehicle use within the entire drainage area, to the top of the slope, and along the stream itself. Transient foot traffic can occur without significant negative impact, but tactical land vehicles should not be permitted to move through these areas. Nearby roads and firebreaks that could lead to erosion and sedimentation should be abandoned and revegetated to the extent possible (LeBlond, F ussell, and Braswell 1994a).

Intensive uses such as occupation and maneuver training are generally prohibited in large floodplains by the mucky soils and high tree densities. However, roadbed stream crossings can be very damaging, and should be designed to prevent erosion and ponding (LeBlond, Fussell, and Braswell 1994a). Training activity can be funnelled into a single crossing point, using telephone poles along the ground to direct troop movements. These limited crossings can be hardened with concrete or rock. Check dams can also be used on both sides of the streambed to minimize sedimentation from upsl opeareas (A. Henry, StateBiologist, N orth Carolina NRCS, 15 September 1995). To keep damage localized, degraded areas should be rehabilitated and reused so high quality areas that serve as TES habitat can be avoided altogether (Russo et al. 1993). 


\section{Conclusions and Recommendations}

\section{Conclusions}

Military training activities have a high potential to alter the characteristics of natural plant communities that provide TES habitat in the southeastern U nited States. Overall, four basic trends are apparent: (1) because many southeastern ecosystems are fire-adapted, military training is potentially beneficial when it ignites growing-season fires that are allowed to spread across the landscape, (2) plant communities that are fire-adapted can probably tolerate losses of vegetation resulting from light to moderate levels of trampling, (3) hydrologic changes and soil erosion dueto military activity, especially tank traffic, havethe potential to destroy some plant communities, to the detriment of plant and animal TES, and (4) degradation resulting from hydrologic and soils impacts has the potential to be less reversiblethan degradation resulting from lack of fire or other land use impacts; in fact, it may be irreversible.

From the literature review, installation site visits, and interviews with DoD personnel and other experts, it is concluded that the ecosystems that support TES and military training are resilient to change and thus can support both TES and training, as long as critical thresholds of disruption to natural processes are not surpassed. At this time, those thresholds cannot be identified through literature review, but managers can begin to establish them by carefully recording all management activities and training schedules, and the resulting effects on species, community, and ecosystem factors through time (for more discussion on the selection of factors for monitoring in this context, see Trame and Tazik 1995).

Land managers and others responsible for TES conservation have been making and will continue to make decisions in the absence of solid data about impacts on natural plant communities. This review demonstrates that current understanding of military effects on TES habitat is lacking, and inflexible opinions about management solutions are premature. Our lack of information can berecognized explicitly, and then gradually diminished through an adaptivemanagement approach toward land management decisionmaking (Trame and Tazik 1995). In adaptive management, management plans and monitoring protocol are developed as large experiments, including appropriate experimental design and sampling methods. 
Management actions are based on current information, but all assumptions and predictions are explicitly stated, so errors can be identified as knowledge improves. In this context, management actions serve as experimental treatments, and ecological factors that are monitored serve as the quantitative variables for evaluating results. If possible, alternative management actions may be implemented side-by-side or with a control site to facilitate analysis of results. The process is successful when it leads to increased understanding about the ecosystem and improved management strategies.

\section{Recommendations}

Current data on potential military impacts to plant communities are minimal, so it is recommended that managers responsiblefor TES conservation initiateadaptive management. Natural resource managers, endangered species biologists, Integrated Training and Management (ITAM) personnel, and military range and traininglands personnel should collaboratetoidentify themost important questions regarding the relationship between TES habitat and training land uses. The same group of people will be required to work together in order to execute management experiments that will result in useful information about how best to integrate the military mission with TES habitat management. Although primary responsibility for TES conservation rests with natural resource managers, involvement of the training community is needed to acquire effective results.

To begin to identify disruption thresholds, land managers may find the following research questions useful to consider:

1. Quantification of degradation through time as a site is used for various training activities: occupation, foot traffic, assembly, maneuver training. How much time occurs before sensitive plant and animal species stop reproducing? disappear?*

2. Quantification of recovery through time under different restoration regimes. How long before soils and hydrology recover? How long before plant populations recover? How long before wildlife habitat values are restored?

3. Measure and describe the landscape level processes that are altered by training in sandhills adjacent to inclusional wetlands or small streams. What

\footnotetext{
Note that the authors do not promote impacts of this magnitude, but do recognize their occurrence, and such circumstances should be used to improve knowledge of military effect thresholds.
} 
buffer zone width is needed to maintain the integrity of soils and hydrology and plant and animal TES populations? How does the buffer zone requirement differ in different terrain?

4. At what level of intensity does land use for occupation/foot traffic/vehicle traffic cause temporary or permanent loss of pyrogenic groundcovers? How can vegetation most effectively be restored? How extensive is the bare area, and does the areal size increase indefinitely through time?

5. Identification of the appropriate planting methods, companion crops, and native seed mixes for effective use of native species for erosion control (D. Lane). Evaluate the risk of invasion from commonly used, proven erosioncontrol vegetation.

6. Quantification of impacts to aquatic species from various levels of sedimentation and various erosion management techniques.

7. Identification of impacts from upland revegetation projects, including fertilization, on plant and animal TES in inclusional wetlands. Identify risks associated with short-term vs. long-term application of fertilizer compared to the risks associated with poor soil stability. I dentify risks associated with a single application vs. multiple applications of fertilizer (S. Parris).

8. Determinethreshold levels of transient foot or mechanical traffic that degrade habitat for TES in high quality uplands communities and wetlands.

9. Determine if restoration of natural hydrology is possible in degraded inclusional wetlands and bottomland hardwoods.

10. Through time, acquire data on which plant communities and which sites are the most sensitive to physical disturbances or erosion and sedimentation processes. The following "recommendations" are consistent with current literature and expert opinion, but are not detailed enough to provide quality decision support. They should be examined quantitatively in the field:

a. Dry communities with sandy soils and lack of surface moisture are probably themost resilient land availablefor mechanized military training in the Southeast. Where possible, avoid the conversion of high quality areas for intensive land uses such as drop zones or multipurpose range complexes. Many acres on most installations have been degraded enough by past land uses that they can nolonger provide habitat for TES. If these 
areas aresuitablefor intensivetraining purposes, such usewould facilitate long-term coexistence of TES and the military mission. Long-term landscape planning can be invoked to determine what areas will function as intensive training sites, what areas will be maintained for TES conservation, and what areas will require aggressive erosion control, according to the needs of military trainers and the capacity of the land to sustain various activities. The 1993-1997 Eglin integrated Natural Resources Management Plan is a solid example of this planning approach (Department of the Air Force 1993).

b. For dry pine communities that are resilient to training, the following priorities are suggested by current ecological information:

(1) Degraded, relatively flat areas should be used before high quality or areas with many streams.

(2) Areas that support TES and areas adjacent to sensitive wetlands should be avoided.

(3) Erosion should be harnessed using natural revegetation methods if possible. No off-site erosion should be allowed to impact downslope communities or streams.

(4) F ragmentation of quality areas should be minimized. Connectivity should be enhanced whenever possible.

c. Off-road marches and other periodic foot traffic can be allowed through fire-adapted communities with minimal impact. Routes may be rotated so communities have the ability to recover from loss of aboveground parts (which may facilitate more realistic training as well).

d. The seasonal timing of training may not significantly affect impacts to natural plant communities (MacRoberts, Weakley). If attempting to use this approach would restrict other options for training or conservation, it should receive a lower priority.

e. TES habitat in inclusional wetlands such as pine savannas and seepage bogs should be off limits to mechanized training. The immediate watershed also should be protected from hydrological impacts.

This study has highlighted the need for rigorous future efforts to test the ideas within this document, as well as any site specific issues that were not presented here. The knowledge base will be greatly improved if DoD installations use adaptivemanagement to document the effects of activities and management actions on natural ecosystems, and publish their findings. Thelack of knowledge about the 
response of natural communities to human activities means DoD installations may wish to diligently document the effects that result (and do not result) from ongoing mission activities. In the long run, improved knowledge will lead to increased control over installation land use decisions, and greater certainty in available options for military training. 


\section{References}

Abrahamson, W.G., and D.C. Harnett. "Pine Flatwoods and Dry Prairies," in R.L. Myers, and J .J . E wel, eds., E cosystems of F Iorida (University of Central Florida Press, 1990)

Anderson, A.B., P.J . Guertin, and D.L. Price, Land Condition Trend Analysis Data: Power Analysis, Technical Report 97/05/ADA321295 (U.S. Army Construction Engineering Research Laboratories [USACERL], October 1996).

Army Environmental Center (AEC), Land Condition Tend Analysis II (LCTA II): Workshop Report (Department of the Army [DA], 1996).

Askew, G.R., and T.M. Williams, "Sediment Concentrations from Intensively Prepared Wetland Sites," Southern J ournal of Applied F orestry, vol 8, no. 3 (1984), pp 152-157.

Aust, W.M., M.D. Tippett, J .A.Burger, and W.H. McKee, J r., "Compaction and Rutting During Harvesting Affect Better Drained Soils More Than Poorly Drained Soils on Wet PineFlats," Southern J ournal of Applied Forestry, vol 19, no. 2 (1995), pp 72-77.

Aust, W.M., T.W. Reisinger, J .A. Burger, B.J . Stokes, "Soil Physical and Hydrological Changes Associated with Logging a Wet Pine Flat with Wide-tired Skidders," Southern J ournal of Applied Forestry, vol 17, no. 1 (1993), pp 22-25.

Beije, H.M., "Effects of Off-Road Locomotion on Soil and Vegetation in Heathland," in Proceedings: NATO CCMS Seminar BlueBook 159, Preservation of Flora and Fauna in Military Training Areas," Conference Proceedings N-87/09/ADA179754 (USACERL, J anuary 1987).

Blackburn, W.H., J .C. Wood, H.A. Pearson, and R.W. Knight, "Storm Flow and Sediment Loss from Intensively Managed Forest Watersheds in East Texas," in Ecological, Physical, and Socioeconomic Relationships Within Southern National Forests, Proceedings of the Southern Evaluation Project Workshop, May 26-27, 1987. United States General Tech Report SO-68 (U.S. Department of Agriculture Forest Service (USDAFS) Southern Forest Experiment Station, 1987).

Blakesley, J .A., and K.P. Reese, "Avian Use of Campground and N oncampground Sites in Riparian Zones," J ournal of Wildlife Management, vol 52, no. 3 (1988), pp 399-402. 
Boyle, S.A., and F.B. Sampson, "Effects of Nonconsumptive Recreation on Wildlife: A Review," WildlifeSociety Bulletin 13 (1985), pp 110-116.

Bridges, E.L., and S.L. Orzell, "Longleaf PineCommunities of the West Gulf Coastal Plain," Natural Areas J ournal, vol 9, no. 4 (1989), pp 246-263.

Brinson, M.M., "Riverine Forests," in A.E. Lugo, M.M. Brinson, and S. Brown, eds., Ecosystems of the World, Volume 15: Forested Wetlands (EIsevier Scientific Press, 1990), pp 87-141.

Christensen, N.L., "Vegetation of the Southeastern Coastal Plain," in M.G. Barbour and W.D. Billings, eds., N orth American Terrestrial Vegetation (Cambridge University Press, 1988).

Cole, D.N., "Research on Soil and Vegetation in Wilderness: a State-of-the-Knowledge Review," in R.C. Lucas, compiler, Proceedings of the National Wilderness Research Conference: Issues, State-of-Knowledge, Future Directions, Report INT-4901 (Intermountain Research Station, 1987).

Cole, D.N., "Disturbance of Natural Vegetation by Camping: Experimental Applications of Low-Level Stress," Environmental Management, vol 19, no. 3 (1995), pp 405-416.

Cole, D.N., and P.B. Landres, "I ndirect Effects of Recreation on Wildlife," in R.L. Knight and K.J . Gutzwiller, Wildlifeand Recreationists: Coexistence through Management and Research (I sland Press, 1995).

Conner, W.H., J .G. Gosselink, and R.T. Parrondo, "Comparison of the Vegetation of Three Louisiana Swamp Sites with Different Flooding Regimes," American J ournal of Botany, vol 68, no. 3 (1981), pp 320-331.

Cowardin, L., V. Carter, F. Golet, and E. LaRoe, Classification of Wetlands and Deepwater Habitats of theU nited States, FWS/OBS-79/31 (U .S. F ish and Wild life Service, 1979).

Dale, D., and T. Weaver, "Trampling Effects on Vegetation of the Trail Corridors of North Rocky Mountain Forests," J ournal of Applied Ecology, vol 11 (1974), pp 767-772.

Day, S.D., N.L. Bassuk, and H. van Es, "Effects of F our Compaction Remediation Methods for Landscape Trees on Soil Aeration, Mechanical Impedance and Tree Establishment," J ournal of Environmental Horticulture, vol 13, no. 2 (1995), pp 6471.

Department of the Army (DA), Integrated Training Area Management (ITAM) Program Strategy (DA 1995). 
DA, Final E nvironmental I mpact Statement, Volume 1: Military Training U se of $\mathrm{N}$ ational Forest Lands, Camp Shelby, Mississippi (DA, J uly 1994).

DA, Biological Assessment of Land-Use Activities on the Karner Blue Butterfly at Ft. McCoy, WI (DA, February 1993).

Department of the Air F orce, Natural Resources Management Plan, Eglin Air ForceBase, 1993-1997 (Eglin Air Force Base, 1993).

Department of Military Affairs (DMA), Draft, Final Environmental Impact Statement of Mission Expansion/ Multiple Construction at Camp Grayling, Michigan (DMA, 5 April 1994).

Dickerson, B.P., "Stormflows and Erosion After Tree-length Skidding on Coastal Plain Soils," Transactions of theAmerican Society of Agricultural Engineers, vol 18 (1975), pp 867-869.

Dickson, R.E., and T.C. Broyer, "Effects of Aeration, Water Supply, and Nitrogen Source on Growth and Development of Tupelo Gum and Bald Cypress," Ecology, vol 53, no. 4 (1972), pp 626-634.

Diersing, V.E., R.B. Shaw, and D.J . Tazik, "US Army Land Condition-Trend Analysis (LCTA) Program," Environmental Management, vol 16, no. 3 (1992), pp 405-414.

Dobrowolski, J .P., W.H. Blackburn, and H.E. Grelen, "Sediment Production for Long-term Burning of a Longleaf Pine-Bluestem Association," in Ecological, Physical, and Socioeconomic Relationships Within Southern National F orests, Proceedings of the Southern Evaluation Project Workshop, May 26-27, 1987. USDAFS General Technical Report SO-68 (Southern F orest Experiment Station, 1987).

Duever, L.C., "Research Priorities for the Preservation, Management, and Restoration of Wiregrass E cosystems," Natural Areas J ournal, vol 9, no. 4 (1989), pp 214-218.

Emrick, V.R., and R. Proffitt, Summarization of the Land Condition Trends Analysis (LCTA) Program at Fort Pickett Military Reservation, for the Years 1994 \& 1995, draft Report (Fort Pickett Fish and Wildlife Management Branch, 1996).

Field Manual [F M] 7-7, TheM echanized I nfantry Platoon and Squad (APC) (Headquarters, Department of the Army [HQDA], March 1985).

FM 5-100, Engineer Combat Operations (HQDA, November 1988).

FM 71-100, Division Operations (HQDA, J une 1990). 
Fischer, R.A., K. Robertson, M.G. Harper, and A. Trame, Bottomland Hardwoods and Deepwater Swamps, draft report (Waterways Experiment Station [WES], in prep).

Florida Exotic Pest Plant Council (FEPPC), "List of Florida's Most Invasive Species," brochure (FEPPC, 1995).

Florida Natural Areas Inventory (FNAI). Eglin Natural Communities Survey: Year One Report (F NAI 1994).

FNAI and Florida Department of Natural Resources (FDNR), Guide to the Natural Communities of Florida (FNAI and FDNR, 1990).

FNAI and The Nature Conservancy (TNC), Camp Blanding Training Site Natural Community Survey, Final Report (FNAI and TNC, 1995).

Frost, C.C., J . Walker, and R.K. Peet, "Fire-Dependent Savannas and Prairies of the Southeast: Original Extent, Preservation Status and Management Problems," in D.L. Kulhavy, and R.N. Conner, eds., Wilderness and Natural Areas in theEastern United States: A Management Challenge (Center for Applied Studies, School of Forestry, Stephen F. Austin State University, 1986), pp 348-357.

Garton, E.O., B. Hall, and T.C. Foin, "The Impact of a Campground on the Bird Community of a Lodgepole Pine Forest," in T.C. Foin, ed., Visitor Impacts on National Parks: the Yosemite Ecological Impact Study, Institute of Ecology Publication No. 10 (University of California, Davis, 1977).

Gill, W.R., and R.D. Miller, "A Method for Study of the Influence of Mechanical I mpedance and Aeration on the Growth of Seedling Roots," Soil ScienceSoci ety Proceedings, vol 20 (1956), pp 154-157.

Goran, W.D., L.L. Radke, and W.D. Severinghaus, An Overview of the Ecological Effects of Tracked Vehicles on Major U.S. Army Installations, TR N-142 (USACERL, February 1983).

Gordon, D.R., and K.P. Thomas, "Introduction Pathways for Invasive Non-Indigenous Species," Draft Report for the Florida State Legislature (Florida Department of Environmental Protection, in prep).

Gosselink, J .G., M.M. Brinson, L.C. Lee, and G.T. Auble et al., "Human Activities and Ecological Processes in Bottomland Hardwood Ecosystems: The Report of the E cosystem Workgroup," in J .G. Gosselink, L.C. Lee, and T.A. Muir, eds., Ecological Processes and Cumulative Impacts (Lewis Publishers, 1990), pp 549-598. 
Greacen, E.L., and R. Sands, "Compaction of Forest Soils, a Review," Australian J ournal of Soil Research, vol 18 (1980), pp 163-89.

Greenberg, C.H., S.H. Crownover, and D.R. Gordon, "Roadside Soils: A Corridor for Invasion of Xeric Scrub by Non-indigenous Plants," Natural Areas J ournal, vol 17, no. 2 (1997), pp 99-109.

Greene, W.D., and W.B. Stuart, "Skidder and Tire Size Effects on Soil Compaction," Southern J ournal of Applied Forestry, vol 9, no. 3 (1985), pp 154-157.

Guertin, P.J ., "Compiled Notes and Bibliographies on I mpacts of Manuever Training and Associated Activities on Plant, Animal and Bird Populations," draft report (USACERL, 1995).

Gulf Engineers and Consultants, Inc., and Geo-Marine, Inc., Final Report, "Rare, Threatened and Endangered Species Survey and Their Habitat at Fort Benning, Georgia," Contract No. DACW21-89-0016 (1994).

Harcombe, P.A., J .S. Glitzenstein, R.G. Knox, S.L. Orzell, and E.L. Bridges, "Vegetation of the Longleaf Pine Region of the West Gulf Coastal Plain," in S.M. Hermann, ed., Proceedings of the Tall Timbers Fire E cology Conference, No. 18, The Longl eaf Pine E cosystem: Ecology, Restoration and Management (Tall Timbers Research Station, 1993), pp 83-104.

Harms, W.R., "Some Effects of Soil Type and Water Regime on Growth of Tupelo Seedlings," E cology, vol 54, no. 1 (1973), pp 188-193.

Harper, M.G., R.A. Fischer, A. Trame, W. Whitworth, and C.O. Martin, Management of Longleaf Pine Woodlands for Threatened and Endangered Species, draft Technical Report (USACERL, in prep).

Harper, M.G., and A. Trame, Management of Herbaceous Seeps and Wet Savannas for Threatened and Endangered Species, draft Technical Report (USACERL, in prep).

Harris, L.D., and J .G. Gosselink, "Cumulative Impacts of Bottomland Hardwood Forest Conversi on on Hydrology, Water Quality and Terrestrial Wildlife," in J .G. Gosselink, L.C. Lee, and T.A. Muir, eds., Ecological Processes and Cumulativel mpacts (Lewis Publishers, 1990), pp 259-322.

Hart, B.L., and G.D. Lester, Natural Communities and Sensitive Species Assessment on Fort Polk Military Reservation, LA, Final Report submitted to Department of the Army Corps of Engineers, Memphis, TN (Louisiana Department of Wildlife and Fisheries and The Nature Conservancy, October 1993). 
Hatchell, G. E., C.W. Ralston, and R.R. F oil, "Soil Disturbances in Logging: Effects on Soil Characteristics and Growth of Loblolly Pine in the Atlantic Coastal Plain," J ournal of Forestry, vol 68 (1970), pp 772-775.

H osner, J .F ., "The Effects of Complete I nundation U pon Seedlings of Six Bottomland Tree Species," Ecology, vol 39, no. 2 (1958), pp 371-373.

H uffman, R.T., and S.W. F orsythe, "Bottomland Hardwood F orest Communities and Their Relation to Anaerobic Soil Conditions," in J .R. Clark and J . Benforado, eds., Wetlands of Bottomland Hardwoods (EIsevier Scientific Publishing Company, 1981), pp 177185.

J ames, T.D.W., D.W. Smith, E.E. Mackintosh, M.K. Hoffman, and P. Monti, "Effects of Camping Recreation on Soil, J ack Pineand U nderstory Vegetation in a N orthwestern Ontario Park," F orest Science, vol 25, no. 2 (1979), pp 333-349.

J ordan, R.A., K.S. Wheaton, and W.M. Weiher, Integrated Endangered Species Management Recommendations for Army Installations in the Southeastern United States: Assessment of Army-wide Management Guidelines for the Red-cockaded Woodpecker on Associated Endangered, Threatened, and Sensitive Species (The Nature Conservancy, 1995).

Kovacic, D.A., A.A. Leff, T.G. Cirarolo, and K.W. McLeod, "Potential Cation Leaching Losses following Disturbance Across a Southeastern Coastal Plain Landscape Gradient," in R.R. Sharitz and J .W. Gibbons, eds., F reshwater Wetlands and Wildlife (U.S. Department of Energy (DoE), Office of Scientific and Technical Information, 1989), pp 113-126.

Kuss, F.R., and A.R. Graefe, "Effects of Recreation Trampling on Natural Area Vegetation," J ournal of Leisure Research, vol 17, no. 3 (1985), pp 165-183.

LeBlond, R.J ., J .O. Fussell, and A.L. Braswell, Inventory of the Rare Species, Natural Communities, and Critical Areas of the Camp Le eune Marine Corps Base, North Carolina (North Carolina Natural Heritage Program, 1994a).

LeBlond, R.J ., J .O. Fussell, and A.L. Braswell, Inventory of the Rare Species, Natural Communities, and Critical Areas of theCherry Point MarineCorpsAir Station, North Carolina (North Carolina Natural Heritage Program, 1994b).

Lockaby, B.G., and C.G. Vidrine, "Effect of Logging E quipment and Traffic on Soil Density and Growth and Survival of Young Loblolly Pine," Southern J ournal of Applied Forestry vol 18, no. 2 (1984), pp 109-112. 
Lowery, R.F., and D.H. Gjerstad, "Chemical and Mechanical Site Preparation," in Forest Regeneration Manual (Kluwer Academic Publishers, Dordrecht, The Netherlands, 1991), pp 251-261.

Lull, H.W., Soil Compaction on Forest Land, Forest Service Misc. Pub. 768 (U.S. F orest Service [USFS], 1959).

Malac, B.F., P.G. Combs, L.F. Holloway, G.G. Langdon, W.J . Mitsch, R. Todd, and H. Riekerk, "Management of Southeastern Bottomland Hardwood F orests: Opportunities and Constraints," in J.R. Clark and J. Benforado, eds., Wetlands of Bottomland Hardwoods (Elsevier Scientific Publishing Company, 1981), pp 335-385.

Martin, C.O., R.A. Fischer, M.G. Harper, D.J . Tazik, and A. Trame, Regi onal Strategies for Managing Threatened and Endangered Species Habitats: A Concept Plan and Status Report, Technical Report SERDP-96-1 (WES, 1996).

McDonnell, M.J ., "Trampling Effects on Coastal Dune Vegetation in the Parker River National Wildlife Refuge, Massachusetts, USA," Biological Conservation, vol 21 (1981), pp 289-301.

Myers, R.L., "Scrub and High Pine," in R.L. Myers and J .J . Ewel, eds., Ecosystems of Florida (University of Central Florida Press, 1990), pp 150-193.

Myers, R.L., and J .J . Ewel, "Problems, Prospects and Strategies for Conservation," in R.L. Myers and J .J . E wel, eds., E cosystems of F lorida (University of Central F lorida Press, 1990).

Michigan Department of Military Affairs (DMA), Draft, Final Environmental Impact Statement of Mission Expansion/ MultipleConstruction at Camp Grayling, Michigan (DMA, 5 April 1994).

Miller, J .H., and D.L. Sirois, "Soil Disturbance by SkylineYarding vs. Skidding in a L oamy Hill Forest," Soil Science Society of America J ournal, vol 50 (1986), pp 1579-1583.

Mitsch, W.F., and J .G. Gosselink, Wetlands (Van Nostrand Reinhold, 1986).

Moehring, D.M., and I.W. Rawls, "Detrimental Effects of Wet Weather Logging," J ournal of F orestry, vol 68 (1970), pp 166-167.

Noss, R.F., “Longleaf Pine and Wiregrass: Keystone Components of an Endangered Ecosystem," Natural Areas J ournal, vol 9, no. 4 (1989), pp 211-213.

O'N eil, L.J ., M.R. Waring, H.G. Hughes, M.C. Landin, M.L. Pearson, P.A. Morris, and R.J . Larson, Proposed 9th Infantry Division Force Conversion: Maneuver Damage, 
Erosion and Natural Resources Assessment, Yakima Firing Center, Washington, Volume I: Main Text, Technical Report EL-90-9 (WES, August 1990).

Outcalt, K.W., and C.E. Lewis, "Response of Wiregrass (Aristi da stricta) to Mechanical Site Preparation," in L.C. Duever, and R.F. Noss, eds., Wiregrass Biology and Management: Maintaining Groundcover Integrity in Long leaf Pine Ecosystems, Proceedings of the Symposium (KBN Engineering and Applied Sciences, $27 \mathrm{~J}$ une 1990).

Patrick, W.H., J r., "Bottomland Soils," in J .R. Clark and J . Benforado, eds., Wetlands of Bottomland Hardwoods (Elsevier Scientific Publishing Company, 1981), pp 177-185.

Patrick, W.H., J r., G. Dissmeyer, D.D. Hook, V.W. Lambou, H.M. Leitman, and C.H. Wharton, "Characteristics of Wetland Ecosystems of Southeastern Bottomland Hardwood Forests," in J .R. Clark and J . Benforado, eds., Wetlands of Bottomland Hardwoods (E Isevier Scientific Publishing Company, 1981).

Peet, R.K., "A Taxonomic Study of Aristida stricta and A. beyrichiana," Rhodora, vol 95 (1993), pp 25-37.

Peet, R.K., and D.J . Allard, "Longleaf Pine Vegetation of the Southern Atlantic and Eastern Gulf Coast Regions: A Preliminary Classification," in S.M. Hermann, ed., Proceedings of the Tall Timbers Fire E col ogy Conference, No. 18, The Longleaf Pine Ecosystem: E cology, Restoration and Management (Tall Timbers Research Station, 1993), pp 45-82.

Penfound, W.T., “Southern Swamps and Marshes," Botanical Review, vol 18 (1952), pp 413446.

Price, D.L., A.B. Anderson, W.R. Whitworth, and P.J . Guertin, Land Condition Trend Analysis Data Summaries: Preliminary Data Applications, Technical Report 95/39/ADA300753 (USACERL, September 1995).

Provencher, L., G. Tanner, D. Gordon, and L. Brennan, “Cross-scale Analysis of Soil, Plant, Invertebrate, and Vertebrate Responses to Restoration Techniques in Degraded Florida Sandhill Systems," draft Annual Report (The Nature Conservancy, 1996).

Reisinger, T.W., G.L. Simmons, and P.E. Pope, "The Impact of Timber Harvesting on Soil Properties and Seedling Growth in theSouth," Southern J ournal of Appli ied Forestry, vol 12 (1988), pp 58-67.

Robertson, K.M., Basin Shrub-dominated Wetlands, draft Technical Report (USACERL, in prep). 
Russo, M.J ., B.A. Sorrie, B. Van Eerden, and P.E. Hippensteel, Rare and Endangered Plant Survey and Natural Area I nventory for Fort Bragg and Camp MacKall Military Reservations, North Carol ina (The Nature Conservancy and North Carolina N atural Heritage Program, 1993).

Schafale, M.P., and A.S. Weakley, Classification of the Natural Communities of North Carolina, Third Approximation (North Carolina Natural Heritage Program, Division of Parks and Recreation, N.C. Department of Environment, Health, and Natural Resources, 1990).

Scott, M.L., B.A. Kleiss, W.H. Patrick, C.A. Segel quist, et al., "The E ffect of Devel opmental Activities on Water Quality Functions of Bottomland Hardwood E cosystems: The Report of the Water Quality Workgroup," in J .G. Gosselink, L.C. Lee, and T.A. Muir, eds., Ecol ogical Processes and Cumulativel mpacts (Lewis Publishers, 1990), pp 411453.

Sharitz, R.R., and W.J . Mitsch, "Southern Floodplain Forests," in W.H. Martin, S.G. Boyce, and A.C. Echternacht, eds., Bi odiversity of the Southeastern U nited States Lowland Terrestrial Communities (J ohn Wiley and Sons, Inc., 1993), pp 311-371.

Sheridan, D., Off-Road Vehicles on Public Land (Council for Environmental Quality, 1979).

Stout, I.J ., and W.R. Marion, "Pine Flatwoods and Xeric Pine Forests of the Southern (lower) Coastal Plain," in W.H. Martin, S.G. Boyce, and A.C. Echternacht, eds., Biodiversity of the Southeastern United States (J ohn Wiley \& Sons, Inc., 1993), pp 373-446.

Swindel, B.F., W.R. Marion, L.D. Harris, L.A. Morris, W.L. Pritchett, L.F. Conde, H. Riekerk, and E.T. Sullivan, "Multi-resource Effects of Harvest, Site Preparation, and Planting in Pine Flatwoods," Southern J ournal of Applied Forestry, vol 7, no. 1 (1983), pp 6-15.

Taylor, H.M., and E. Burnett, "Influence of Soil Strength on the Root-Growth Habits of Plants," Soil Science, vol 98 (1964), pp 174-180.

Taylor, J .R., M.A. Cardamone, and W.J . Mitsch, "Bottomland Hardwood Forests: Their Functions and Values," in J.G. Gosselink, C.L. Lyndon, and T.A. Muir, eds., Ecological Processes and Cumulative Impacts: Illustrated by Bottomland Wetland E cosystems (Lewis Publishing, Inc., 1990), pp 13-86.

Tazik, D.J ., J.D. Cornelius, D.M. Herbert, T.J. Hayden, and B.R. J ones, Biological Assessment of the Effects of Military Associated Activities on Endangered Species at Fort Hood, Texas, Special Report EN-93/01/ADA263489 (USACERL, December 1992). 
Thorud, D.B., and S.S. Frissell, J r., Time Changes in Soil Density F ol lowing Compaction Under an Oak Forest, Research Note 257 (Minnesota Department of Forestry, 1976).

Threatened and Endangered Species Working Group, U.S. Army Threatened and Endangered Species Research and Development Program: A Concept PIan and Status Report, draft Technical Report (USACERL, in prep).

Thurow, T.L., S.D. Warren, and D.H. Carlson, "Tracked Vehicle Traffic Effects on the Hydrologic Characteristics of Central Texas Rangeland," Transactions of the American Society of Agricultural Engineers, vol 36, no. 6 (1993), pp 1645-1650.

Trame, A., Known and Potential Impacts of Maneuver Training, Especially Physical Disturbance, on Threatened and Endangered Species, TR96/70 (USACERL, April 1997).

Trame, A., and D.J . Tazik, Thel mplications of E cosystem Management for Threatened and Endangered Species Conservation by the U.S. Army, Technical Report 95/27/ADA302406 (USACERL, September 1995).

Trumbull, V.L., P.C. Dubois, R.J . Brozka, and R. Guyette, "Military Camping I mpacts on Vegetation and Soils of the Ozark Plateau,"J ournal of Environmental Management, vol 40 (1994), pp 329-339.

Turner, R.E., S.W. Forsythe, and N.J . Craig, "Bottomland Hardwood Forest Land Resources of the Southeastern United States," in J .R. Clark and J . Benforado, eds., Wetlands of Bottomland Hardwood Forests (Elsevier, 1981), pp 13-29.

U.S. Fish and Wildlife Service (USFWS). Chapman's Rhododendron Recovery Plan (USFWS, 1983).

Vachta, E.G., and R.E. Riggins, Erosion Control Management Plan for Army Training Lands, TR N-90/11/ADA226558 (USACERL, J uly 1990).

Ward, J .V., "Riverine-Wetland Interactions," in R.R. Sharitz and J .W. Gibbons, eds., Freshwater Wetlands and Wildlife (U.S. Department of Energy (DoE), Office of Scientific and Technical Information, 1989), pp 385-400.

Webb, R.H., "Compaction of Desert Soils by Off-Road Vehicles," in R.H. Webb and H.G. Wilshire, eds., Environmental Effects of Off-Road Vehicles: I mpacts and Management in Arid Regions (Springer-Verlag, 1983), pp 51-79.

Wharton, C.H., The Natural Environments of Georgia (Geologic and Water Resources Division and Resource Planning Section, Office of Planning and Research, Georgia Department of Natural Resources, 1978). 
Wood, J .C., W.H. Blackburn, H.A. Pearson, T.K. Hunter, and R.W. Knight, "Assessment of Silvicultural and Grazing Treatment Impacts on Infiltration and Runoff Water Quality of Longleaf- slash Pine Forest, Kisatchie National Forest, Louisiana," in Ecological, Physical, and Socioeconomic Relationships Within Southern National F orests, Proceedings of the Southern Evaluati on Project Workshop, May 26-27, 1987, USDAFS General Technical Report SO-68 (Southern Forest Experiment Station, 1987).

Yoho, N.S., "Forest Management and Sediment Production in the South; A Review," Southern J ournal of Applied Forestry, vol 4, no. 1 (1980), pp 27-36.

Yorks, T.P., N.E. West, and R.J . Mueller, Literature Review and Summarization of the Tolerance of Plant Materials to Vehicle and Foot Traffic, unpublished report submitted to USACERL (1993).

Young, P.J ., B.D. Keeland, and R.R. Sharitz, "Growth Response of Baldcypress (Taxodium distichum (L.) Rich.) to an Altered Hydrologic Regime," American Midland Naturalist, vol 133 (1995), pp 206-212. 


\section{Appendix A: List of Personal Communications Cited}

Anderson, Alan, Environmental Biologist, USACERL, 1995.

Dubois, Paul, Ecologist, USACERL, 15 April 1996.

Emrick, Verl, Research Fellow, USACERL, 15 April 1996.

Hansard, Roger, Plant Materials Specialist, North Carolina Natural Resources Conservation Service (NRCS), 14 September 1995.

Henry, Albert, State Biologist, North Carolina NRCS, 14 September 1995.

Imlay, Dr. Marc, Natural Resource Specialist, Army National Guard Bureau, 18 August 1995.

J ohnson, J ohn, Forester, Alabama NRCS, 27 September 1995.

J ones, Mark, LCTA Coordinator, Fort Bragg, NC, 19 March 1996.

Lane, David, Manager, J amie L. Whitten Plant Materials Center, Mississippi NRCS, 12 September 1995.

Macia, Tom, ITAM Program Officer, Training Directorate, Office of the Deputy Chief of Staff for Operations and Plans, Washington, DC, 15 February 1996.

MacRoberts, Barbara, Botanist, Bog Research, Shreveport, LA, 24 J uly 1995.

MacRoberts, Dr. Michael, Botanist, Bog Research, Shreveport, LA, 24 J uly 1995.

Nelson, J ohn, Botanist, University of South Carolina, 10 May 1995.

Parris, Steve, Ecologist, Fort Polk, LA, 25 J uly 1995. 
Pittman, Bert, Community Ecologist, South Carolina Natural Heritage Program, 10 May, 1995.

Proffitt, J oe, LCTA Coordinator, Ft. Pickett Fish and Wildlife Management Branch, 6 March 1996.

Schafale, Michael, Community Ecologist, North Carolina Natural Heritage Program, 11 May 1995.

Shipley, J anet, Endangered Species Biologist, Fort Bragg, NC, 11 May 1995.

Smith, Latimore, Community Ecologist, Louisiana Natural Heritage Program, J anuary 1997.

Stewart, Earl, Biologist, Kisatchie National Forest, Louisiana, 9 May 1995.

Stewart, Rhonda, Botanist/E cologist, Kisatchie National F orest, 9 May and 24J uly 1995.

USFS representative, 1995.

Weakley, Allen, Southeast Regional Office, the N ature Conservancy, 12 May 1995.

Williamson, J erry, Range Soil Conservationist, Interagency Personnel Agreement position with the Army Environmental Center, 18 December 1995. 


\section{Appendix B: LCTA Data Sources for Assessing Military Impacts to Natural Communities}

\section{Brief History of the LCTA Program}

In 1984, the Secretary of the Army directed a study to review natural resource management in the Army. The study's findings suggested that land use planning and erosion control required closer coordination between land managers and military trainers (Department of the Army [DA] 1995). To meet this goal, in part, several recommendations were developed by an independent panel (Table B1), which influenced the creation of a standardized Army inventory and monitoring system, the Land Condition-Trend Analysis (LCTA) program (Diersing, Shaw, and Tazik 1992).

The LCTA program was originally designed to monitor installation-wide trends in land condition, which would, in turn, facilitate comparison among installations. The program was conceived to provide very broad assessment of (1) the land's condition over time, and (2) its ecological capacity to withstand military training.

Table B1. Panel recommendations that influenced the development of the Army LCTA program.

1. Match, to the extent possible, needs for military training activities with the ecological compatibility of the landscape types (deserts, grasslands, forests, etc.) available at various installations.

2. Realign Corps and military budget procedures to place more emphasis on natural resource management.

3. Develop and maintain natural resource management plans that are based on current resource inventories and that contain clearly stated resource-use objectives, site-specific prescriptions, and monitoring procedures designed to evaluate action strategies through integrated resource management.

4. Require that new or more adequate natural resource inventories be completed on all military installations.

5. Establish a designated task force or cadre of personnel at each military installation to prevent, correct, and manage soil erosion and to manage vegetation in military training areas.

(Source: Diersing, Shaw, and Tazik 1992). 
Since then, perceptions of the use of LCTA data have changed, and many new applications of the data have been suggested. It is reasonable to ask whether existing or future LCTA data can be used to describe changes to the natural plant communities on military lands, and whether the program can assess impacts of military training on the habitats of TES.

\section{Current LCTA Program Vision}

In April 1995, U.S. Army Forces Command (FORSCOM) sponsored a meeting to evaluate the methods and objectives of LCTA. Several issues were identified that indicate that LCTA data are not appropriate for assessing military-related impacts to natural communities. Thefol lowing limitations wereidentified by the April 1995 meeting participants: (1) current standard LCTA plot al location and field methods do not provide adequate data for decisionmaking; they do not provide the sitespecific information needed for site restoration activities or proper allocation of training activities to certain parcels of land; and (2) detailed land use information is not available to use for data analysis and interpretation. In October 1995, the Army decided to redefine and redesign the LCTA program and call it "LCTA II" (T. Macia, ITAM Program Officer, Training Directorate, Office of the Chief of Staff for Operations and Plans, professional discussion, 15 February 1996; Army Environmental Center [AEC] 1996). I ts purpose will be to provide an improved approach and methodology to inventory and monitor the natural resources in accordance with user requirements. The new vision for LCTA is under development by the professionals who manage the program at the installation, Major Army Command (MACOM), and Headquarters levels. In J anuary and August 1996, additional workshops were held to determine, on an ecoregional basis, the information required by military trainers, testers, and natural resource professionals from LCTA II (e.g., the user requirements). One of the four major information needs is to "identify impacts on resources (spatial emphasis) by trainers/testers and nonmilitary land users at various intensities (activities, frequencies, duration)" (AEC 1996). This need has not been met by the original LCTA program.

\section{Basic Limitations in LCTA for Impact Assessment of Natural Communities}

From a TES perspective, there are limitations to using LCTA data as a major source of information about impacts to natural communities. LCTA data collection may be at the wrong scale to evaluate impacts to TES. The magnitude of disturbance that renders a location unsuitable habitat for TES may be much less than the magnitude of disturbance that renders the same location unsuitable for 
further military operations, or requires restoration through Land Rehabilitation and Maintenance (LRAM) activities. Since LCTA was originally designed to directly support training decisions based on the capacity of the land to sustain training, it has been geared toward detection of soil and vegetation disruptions that may be much larger than changes which impact TES habitat quality. The original intent of the LCTA program also led to a sampling design that serves large-scale, general questions. Reducing data analysis to include only one plant community type may very well reduce the sample size to an unacceptably small value (Anderson, Guertin, and Price 1996). It is unreal istic to expect a single monitoring program to provide landscape-level training decision-support data and to also evaluate the condition of relatively high-quality natural communities to support TES. Installations require monitoring of land condition at many scales for various purposes.

The type of data collected by LCTA may also be inappropriate for evaluating impacts to TES habitat. Some changes to communities are detectable only when an evaluation is made at the community or watershed level. Standard LCTA protocol does not require the identification of plant communities nor quality evaluations of natural communities, twoimportant considerations when evaluating TES habitat. For example, changes in plant community type and quality due to fire suppression or drainage of a wetland may bedifficult to measureand describeusing standardized LCTA transect methodology. These types of impacts could be evaluated by special-use plots and modified methods within the LCTA II program, but measurements of this nature have not been a goal of LCTA to date and generally have not been done to evaluate the impacts of military training on TES. Even in cases where appropriate data have been collected, many installations have not yet organized and analyzed their data (A. Anderson, Environmental Biologist, USACERL, professional discussion, 1995).

Traditional plot al location led to few transects in areas where military training and TES habitat coexist, again leading to sampling size concerns. Plot allocation in LCTA ignored different land uses within training areas. Instead, the entire installation was sampled as a unit. As a result, most LCTA plots were allocated in areas with little or no training use, and entire training areas were missed by the monitoring program. Plots were not al located to known plant communities; instead, they were allocated based on satellite imagery focusing on soil type. Areas of less than 2 ha in size were excluded, so the program missed small inclusional plant communities (P. Dubois, Ecologist, USACERL, professional discussion, 15 April 1996). Small, wetland communities found throughout the longleaf pine ecosystem arestrongly affected by processes occurring in thesurrounding landscape and often support TES plants. 
The most significant drawback to using the LCTA program for the purpose of impact assessment is that control over military activities is not feasible, so scientific experimentation and quantification is not possible. Thetypeand extent of information collected allows only broad inferences about the effects of activities on soils, vegetation, and wildlife at the installation level (Price et al. 1995). Related data collection deficiencies were discussed at the 1995 and 1996 LCTA/LCTA II workshops. Installation data forms illustrate the type and quantity of data that is collected on standard LCTA plots. Military land use is listed in the following categories: none, wheeled, tracked, excavation, foot bivouac, demolition, and other. Field crews evaluate the presence or absence of each training activity in the past year through visual inspection of the site. Tracks in the ground usually indicate vehicle activity, while Meals Ready-to-E at (MRE) wrappers indicate occupation of land or foot training, etc. This level of knowledge about training activities is not sufficient to rigorously assess potential impacts to natural communities.

\section{Installation Examples}

Below aretwo examples of installations with progressive LCTA implementation, for which community-level impact assessment remains problematic.

\section{Fort Pickett}

LCTA plots on F ort Pickett wereall ocated to ensurerepresentation of all geographic areas that appeared unique based on cultural features or distinct vegetative differences (Emrick and Proffitt 1996). Baseline data to identify plant communities were collected at Fort Pickett in 1994. In 1995, sites that showed signs of human activity were sampled again to measure disturbance impacts. However, data to correlate human activites with changes in plant communities have yet to be analyzed (V. Emrick, Research Fellow, USACERL, professional discussion, 7 February 1997). The database will be used to identify sudden changes in species composition, such as a sudden increase in weedy species, or the sudden disappearance of sensitive species. In the future, installation personnel at Fort Pickett hope to obtain software that will correlate weather history, training use intensity data from Range Control, and LCTA disturbancevariables to estimatethe capacity of each site to withstand training use under varying weather conditions ( ) . Proffitt, LCTA Coordinator, Fort Pickett Fish and Wildlife Management Office, professional discussion, 6 March 1996). The disturbance variables that are collected on Fort Pickett include: percent ground cover, percent aerial vegetation cover, percent area degraded (divided into five classes of severity), percent area in active gullies, percent exposed ground, percent live plant material, and canopy 
composition and structural measures. Military activities are visually assessed, as described above.

\section{Fort Bragg}

Fort Bragg's LCTA field crews identify military activities through the standard LCTA data format. Twotypes of erosion (sheet and gully), ground cover types (bare ground, litter, duff, deadwood, and rock) and disturbance (none, road, trail, pass, and other) are visually estimated. To date, no method is available to do statistical correlations between land use and variables such as percent cover or species diversity. These characteristics are controlled very strongly by the fire history of the site. After a fire, measured values for percent cover and plant species diversity steadily increase for several years. When the site burns, both measures fall dramatically and the cycle begins again. Until additional field work and statistical solutions are able to provide additional insight into the relative importance of fire vs. Iand use activities on these measures, the LCTA program at F ort Bragg cannot provide accurate impact assessments of military training (or any other activity besides fire) on TES (M. J ones, LCTA Coordinator, Fort Bragg, professional discussion, 19 March 1996). 


\title{
Abbreviations and Acronyms
}

\author{
AEC Army Environmental Center \\ DA Department of the Army \\ DMA Michigan Department of Military Affairs \\ DOE Department of Energy \\ DoD Department of Defense \\ ESA Endangered Species Act \\ FDNR Florida Department of Natural Resources \\ FM U.S. Army Field Manual
}

FNAI Florida Natural Area Inventory

FORSCOM U.S. Army Forces Command

HQDA Headquarters, Department of the Army

HMMWV High Mobility Multi-Purpose Wheel ed Vehicle

ITAM Integrated Training and Management

LCTA Land Condition-Trend Analysis

LRAM Land Rehabilitation and Maintenance program

MACOM Major Army Command

MRE Meals Ready to Eat 
NHP Natural Heritage Program

NRCS Natural Resource Conservation Service

ORV off-road vehicle

RCW red-cockaded woodpecker

SERDP Strategic Environmental Research and Development Program

TES threatened and endangered species

TNC The Nature Conservancy

USACERL U.S. Army Construction Engineering Research Laboratories

USFS U.S. Forest Service

USGS U.S. Geologic Survey

USFWS U.S. Fish and Wildlife Service

WES U.S. Army Engineer Waterways Experiment Station 


\section{USACERL DISTRIBUTION}

Chief of Engineers ATTN: CEHEC-IM-LH (2) ATTN: CEHEC-IM-LP (2) ATTN: CECC-R ATTN: CERD-L

Army Headquarters ATTN: DAIM-ED-N (5) ATTN: DAMO-TRO ATTN: ANOP ATTN: AMSTE-EQ ATTN: SFIM-AEC-ECN ATTN: ATIC-CTS ATTN: FKEN-EN ATTN: AEAGC-TD-MO ATTN: EAGC-TD-RMD ATTN: APOP-TR ATTN: APEN-EV

US Army Europe ATTN: AEAEN-ENVR 09114 100th Support Group ATTN: AETT-EN-DPW 09114

CMTC Hohenfels 09173 ATTN: AETTH-DPW

\section{FORSCOM}

Fts Gillem \& McPherson 30330 ATTN: AFOP-TE ATTN: AFOP-TSR ATTN: AFPI-ENE

Installations:

Fort Indiantown Gap 17003 ATTN: AFKA-ZQ-DE-E

Fort AP Hill 22427 ATTN: ANAP-PWE ATTN: AFZM-FHE

Fort McPherson 30330 ATTN: AFZK-EH-E

Fort Riley 66442 ATTN: AFZN-DE-V-N

Fort Polk 71459 ATTN: AFZH-DE-EN

Fort Sam Houston 78234 ATTN: AFZG-DE-EM

Fort Lewis 98433 ATTN: AFZH-DE-Q

Fort Carson 80913 ATTN: AFZC-ECM-NR

Fort Bragg 28307 ATTN: AFZA-PW-DW

Fort Campbell 42223 ATTN: AFZB-DPW-E

Fort McCoy 54656 ATTN: AFZR-DE-E

Fort Pickett 23824 ATTN: AFZA-FP-E

Fort Stewart 31314 ATTN: AFZP-DEV

Fort Buchanan 00934 ATTN: AFZK-B-EHE
Fort Devens 01433 ATTN: AFZD-DEM

Fort Drum 13602 ATTN: AFZS-EH-E

Fort Irwin 92310 ATTN: AFZJ-EHE-EN

Fort Hood 76544 ATTN: AFZF-DE-ENV

Fort Hunter Liggett 93928 ATTN: AFZW-HE-DE

Yakima Tng Center 98901-5000 ATTN: AFZH-Y-ENR

Fort Dix 08640 ATTN: ATZD-EH

\section{TRADOC}

Fort Monroe 23651 ATTN: ATBO-FE

Installations:

Fort Lee 23801 ATTN: ATZM-PTS-T

Fort Jackson 29207 ATTN: ATZJ-PWN

Fort Gordon 30905 ATTN: ATZH-DIE

Fort Benning 31905 ATTN: ATZB-PWN

Fort McClellan 36205 ATTN: ATZN-EM

Fort Rucker 36362 ATTN: ATZQ-DPW-EN

Fort Leonard Wood 64573 ATTN: ATZT-DPW-EE

Fort Leavenworth 66027 ATTN: ATZL-GCE

Fort Bliss 79916 ATTN: ATZC-DOE

Carlisle Barracks 17013 ATTN: ATZE-DPW-E

Fort Eustis 23604 ATTN: ATZF-PWE

Fort Chaffee 72905 ATTN: ATZR-ZF

Fort Sill 73503 ATTN: ATZR-B

Fort Huachuca 85613 ATTN: ATZS-EHB

Fort Knox 40121 ATTN: ATZK-PWE

USAMC Instal \& Srvc Activity ATTN: AMXEN-M 61299

Rock Island Arsenal ATTN: AMSMC-EHR ATTN: SMCRI-PWB

White Sands Missile Range ATTN: STEWS-ES-E

US Army Dugway Proving Ground ATTN: STEDP-EPO-CP

US Army Yuma Proving Ground ATTN: STEYP-ES-E
Aberdeen Proving Ground ATTN: STEAP-SH-ER

National Guard Bureau 20310

ATTN: NGB-ARE

ATTN: NGB-ARI

ATTN: NGB-ARO-TS

Army National Guard

Ft. Richardson, AK 99505-5800

Phoenix, AZ 85008-3495

Sacramento, CA 95826-9101

Boise, ID 83705-8095

Jackson, MS 39209

Camp Shelby, MS 39407-5500

Oklahoma City, OK 73111-4389

Draper, UT 84020-1776

Braggs, OK 74423

Reading, MA 01867-1999

Camp Edwards, MA 02542-5003

Richmond, VA 23219

Columbia, SC 29201

Eastover, SC 29244

St. Augustine, FL 32085

Starke, FL 32091

Indianapolis, IN 46241

Lansing, MI 48913

Little Falls, MN 56345

Jefferson, MO 65101

Camp Roberts, CA 93451

Camp Robinson, AR 72118-2200

US Military Academy 10996

ATTN: MAEN-EV

ATTN: DOPS

US Army Research Laboratory ATTN: AMSRL-OP-SDFE

US Govt Printing Office 20401 ATTN: Rec Sec/Deposit Sec

Defense Technical Info Ctr 22304 ATTN: DTIC-FAB

102 $1 / 97$ 